\title{
Climate variability in Andalusia (southern Spain) during the period 1701-1850 based on documentary sources: evaluation and comparison with climate model simulations
}

\author{
F. S. Rodrigo ${ }^{1}$, J. J. Gómez-Navarro ${ }^{2}$, and J. P. Montávez Gómez ${ }^{2}$ \\ ${ }^{1}$ Departamento de Física Aplicada, Universidad de Almería, La Cañada de San Urbano, s/n, 04120, Almería, Spain \\ ${ }^{2}$ Grupo de Modelización Atmosférica Regional, Departamento de Física, Universidad de Murcia, Spain \\ Correspondence to: F. S. Rodrigo (frodrigo@ual.es)
}

Received: 17 June 2011 - Published in Clim. Past Discuss.: 7 July 2011

Revised: 23 November 2011 - Accepted: 24 November 2011 - Published: 10 January 2012

\begin{abstract}
In this work, a reconstruction of climatic conditions in Andalusia (southern Iberian Peninsula) during the period 1701-1850, as well as an evaluation of its associated uncertainties, is presented. This period is interesting because it is characterized by a minimum in solar irradiance (Dalton Minimum, around 1800), as well as intense volcanic activity (for instance, the eruption of Tambora in 1815), at a time when any increase in atmospheric $\mathrm{CO}_{2}$ concentrations was of minor importance. The reconstruction is based on the analysis of a wide variety of documentary data. The reconstruction methodology is based on counting the number of extreme events in the past, and inferring mean value and standard deviation using the assumption of normal distribution for the seasonal means of climate variables. This reconstruction methodology is tested within the pseudoreality of a high-resolution paleoclimate simulation performed with the regional climate model MM5 coupled to the global model ECHO-G. The results show that the reconstructions are influenced by the reference period chosen and the threshold values used to define extreme values. This creates uncertainties which are assessed within the context of climate simulation. An ensemble of reconstructions was obtained using two different reference periods (1885-1915 and 1960-1990) and two pairs of percentiles as threshold values (10-90 and 25-75). The results correspond to winter temperature, and winter, spring and autumn rainfall, and they are compared with simulations of the climate model for the considered period. The mean value of winter temperature for the period $1781-1850$ was $10.6 \pm 0.1^{\circ} \mathrm{C}\left(11.0^{\circ} \mathrm{C}\right.$ for the reference period 1960-1990). The mean value of winter rainfall for the period $1701-1850$ was $267 \pm 18 \mathrm{~mm}$ (224 mm for 1960
\end{abstract}

1990). The mean values of spring and autumn rainfall were $164 \pm 11$ and $194 \pm 16 \mathrm{~mm}$ (129 and $162 \mathrm{~mm}$ for $1960-1990$, respectively). Comparison of the distribution functions corresponding to $1790-1820$ and 1960-1990 indicates that during the Dalton Minimum the frequency of dry and warm (wet and cold) winters was lower (higher) than during the reference period: temperatures were up to $0.5^{\circ} \mathrm{C}$ lower than the 1960-1990 value, and rainfall was $4 \%$ higher.

\section{Introduction}

Anthropogenic influences on climate overlie a background of natural climate variability that may diminish or increase the same (IPCC, 2007). The lack of instrumental surface temperature and precipitation records prior to the mid-19th century underlines the need to reconstruct the history of climate changes from proxies of climate variability derived from the environment itself and from documentary sources (Rutherford et al., 2005).

Among proxy data, documentary evidence, that is, noninstrumental man-made sources, deserve special attention, because in general they record climatic anomalies and extreme events, such as droughts and floods, making it possible to relate such events to climatic changes. A great number of papers have been published using the methodological basis of historical climatology (a complete review may be consulted in Brázdil et al., 2005, 2010b). Several areas of the Iberian Peninsula (hereafter IP) have been subject of climatic reconstructions including Catalonia (Barriendos, 1997) and Aragon (Vicente-Serrano and Cuadrat, 2007), 


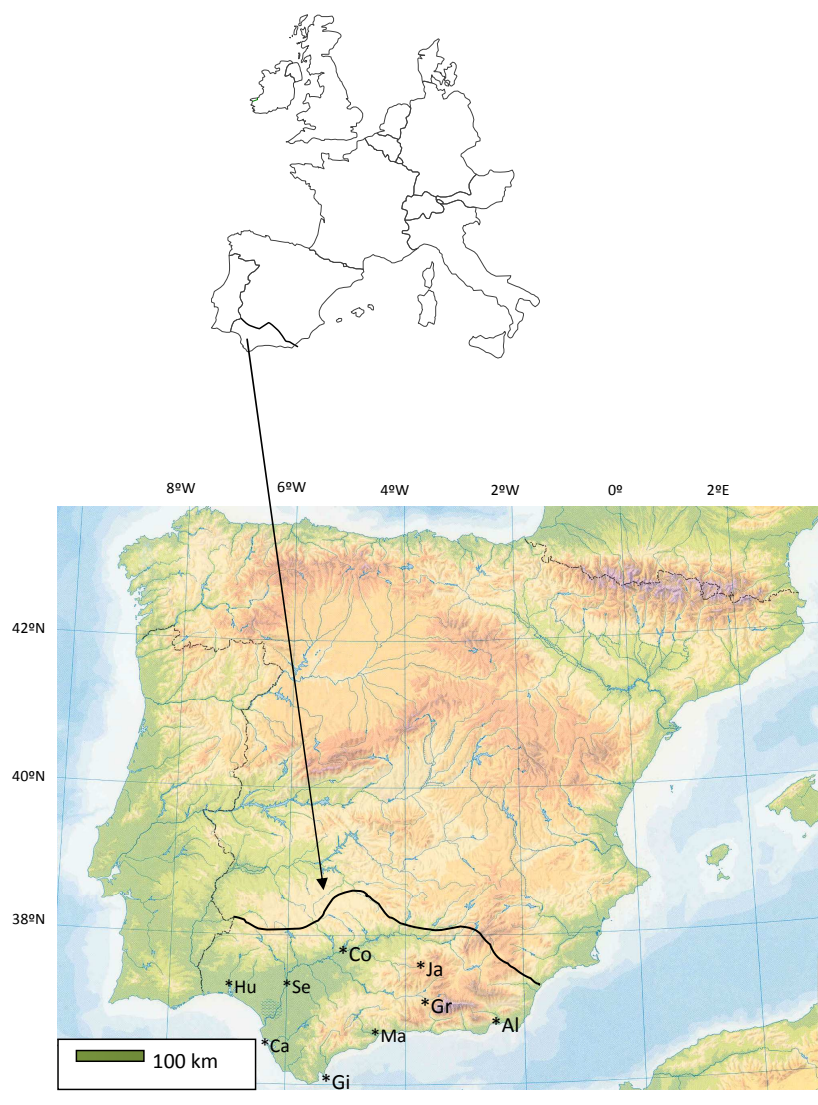

Fig. 1. Map of the study region. Main cities with instrumental and documentary data are indicated (code in Table 1).

Portugal (Alcoforado et al., 2000; Taborda et al., 2004), and Castile, a central region in Spain (Rodrigo et al., 1998; Bullón, 2008; Domínguez-Castro et al., 2008). In addition, various studies coordinating data for the entire Iberian Peninsula have been published, related to flood events in Spanish river basins since $1500 \mathrm{AD}$ (Barriendos and Rodrigo, 2006), droughts during the 17th century and the first half of the 18th century (Domínguez-Castro et al., 2010), and seasonal and annual rainfall variability from the 16th to 20th centuries (Rodrigo and Barriendos, 2008).

The climate of Andalusia (southern Spain, Fig. 1) is Mediterranean, but with a strong influence of the Atlantic Ocean, mainly to the west of the region. The latitude (around $37^{\circ} \mathrm{N}$ ), midway between the temperate oceanic climate zone to the north and the warm tropical one to the south, produces atmospheric behavior of transition between two climates. Its geographical position (southwestern Europe) exposes it to the typical influences of the planetary temperate zone of middle latitudes, as well as certain tropical influences (Martín-Vide, 2007). Therefore, the study of this region is of great interest.

Previous historical climatology studies in this region have analyzed the annual (Rodrigo et al., 2000) and winter (Rodrigo, 2008) rainfall variability since the 16 th century. In historical climatology it is always possible to find new documentary data that compel us to revise analysis. Therefore, the main objective of this work is to improve the reconstructions of the past Andalusian climate, adding new records covering the period from 1701 to 1850 , especially from 1780 onwards. This period includes the Dalton Minimum (Wagner and Zorita, 2005) between approximately 1790 and 1830, a period characterized by a minimum in solar irradiance and intense volcanic activity, with the Tambora eruption in April 1815 as main event (Trigo et al.,2009). From a climatic point of view, therefore, the analysis of climatic data during this period is particularly interesting due to the role of these external forcing factors (Wagner and Zorita, 2005; Trigo et al., 2009). An additional source of information on past climate variability is provided by climate model simulations. The analysis of model responses to external forcing, changes in atmosphere and ocean mechanisms contributing to natural climate variability as well of comparisons between model and proxy data help to improve our understanding of past climate variability (Brázdil et al., 2011). Therefore, other important objectives of this work are an evaluation of the reconstruction method using climate model simulations, and a comparison of climate reconstructions with climate model simulations.

The paper is organized in the following way: data are presented in Sect. 2 (a list of new documentary sources is included in Appendix A), and the reconstruction methodology used is explained in Sect. 3. Section 4 presents the main results, in Sect. 5 these results are compared with other data, and conclusions and challenges for future research are presented in Sect. 6.

\section{Data}

\subsection{Documentary data}

Andalusian historical weather records were obtained by the rigorous analysis of original documents from a variety of sources: urban records, city and religious chronicles, brief reports of events, private correspondence, church records and city archives, medical studies, newspapers, etc. The criteria followed in analyzing the reliability of sources are time-space closeness to the event, reliable transmission of oral or written information, cross-information from different sources, a good agreement among contemporary proxy data such as agricultural production, and the accuracy of authors in describing well known non-weather events, e.g. military and political events, plagues, famines, epidemics, eclipses and earthquakes. The advantage of using different kinds of source lies in the fact that it allows for an adequate crosscomparison of the news collected, and assists in eliminating errors and/or vague terms in the original documents. Consequently, such methodology partially eliminates the subjectivity inherent in this kind of data. Data sources used in 
previous works (Rodrigo et al., 1999; Rodrigo, 2008) have been enlarged, adding new data sources recently discovered, basically early newspapers and medical studies. From the late years of the 18th century to the first decades of the 19th century, anonymous observers began to send their meteorological observations to local newspapers to ensure that people were informed of them. Instrumental daily meteorological data appear in most of them. Although their spatiotemporal coverage is incomplete, these data sources may complete the description of general climatic conditions as well as the nature and character of extreme events in the past. Empirical research of a medical and geographical nature began in Spain in the 18th century with a set of studies that considered the strong influence of climate and environment on the appearance of illness and epidemics. These studies are called "medical topographies", and on many occasions, they included meteorological observations made by physicians. A summary of the new data sources used in this work is shown in Appendix A.

The compiled reports were first codified. This allowed the ordering of information into time-space and type (rain, thermal, wind, cloudiness). Most data relate to Seville and the Guadalquivir River Basin (46.4\%), Granada together with Sierra Nevada Mountains (14.0\%), and Malaga on the Mediterranean coast $(13.4 \%)$. Most data correspond to rainrelated phenomena $(68 \%)$, basically extreme events, such as continuous and intense rainfall, floods and droughts, but $15 \%$ of the records are related with the thermal regime (heat and cold waves, frosts, snowfalls) and $17 \%$ of the records related to other events, such as winds and fogs. In the case of temperatures, the subjective appraisals of the authors on the degree of cold or heat were only taken into account when they were associated with more objective observations, such as those related to frosts, snowfalls, thunderstorms, etc, or when they referred to unusually extreme weather. News related with frosts, snowfalls, or excessive cold unusual for the season (spring, summer) were considered as cold extremes. News related with heat in months when it is not usual (between November and February), or convective storms between the end of spring and the beginning of the autumn (May to September) were considered as warm extremes, since these phenomena are related with the relative low-pressure presence of thermal origin in the IP. Time resolution depends on the data source, varying from daily $(57.6 \%)$ to annual $(7 \%)$. For the purposes of this study, a seasonal resolution was chosen, considering the seasons of the year in the usual way, that is, winter $=$ December to February, spring $=$ March to May, summer $=$ June to August, and autumn = September to November. The information varies seasonally, with $36.6 \%$ of the news referring to winter, $25.4 \%$ to autumn, $22.9 \%$ to spring, and $15.1 \%$ to summer. This distribution is a result of the interest of data sources affecting the state of agriculture and the evolution of crops, especially wheat sown in autumn and harvested in early June. (a) Records per year

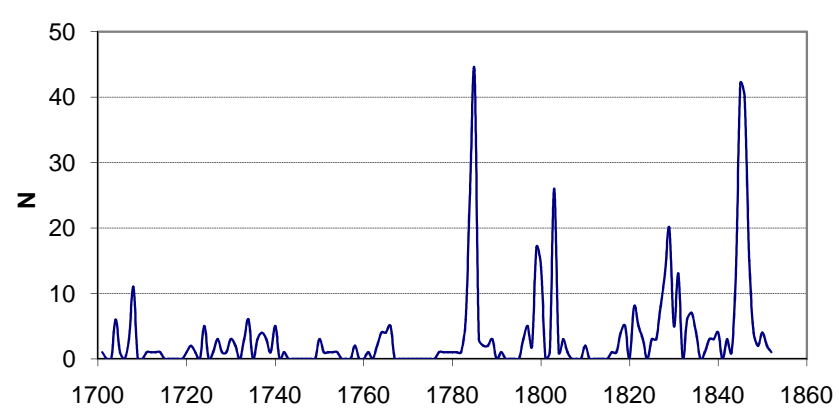

(b) Records per decade

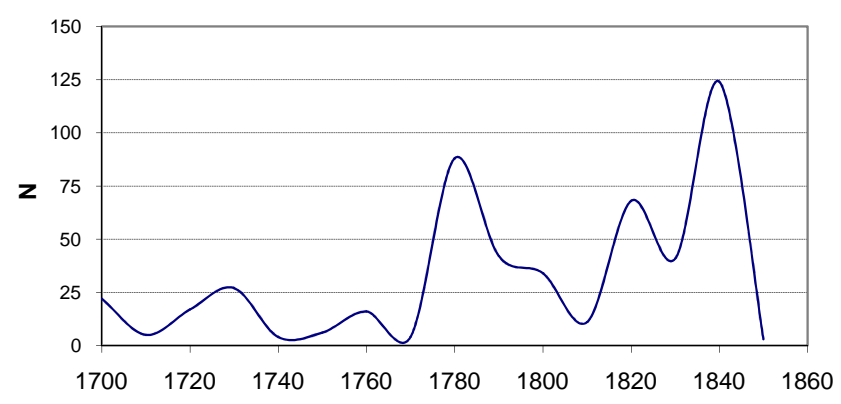

Fig. 2. Number of records from documentary sources, (a) by year, (b) by decade, during the period 1701-1850.

Documentary data refer to the period 1701-1850 (from 1851 onwards available instrumental data were at least with monthly resolution). For the entire period from 1701 to 1850 ,

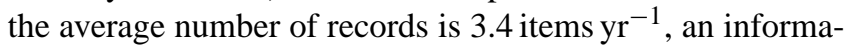
tion density higher than that from previous studies for this region (2.6 items $\mathrm{yr}^{-1}$, see Rodrigo et al., 1999). The time coverage of these data is shown in Fig. 2, which shows the number of records per year and decade. It may be seen that the density of information increases notably from 1780s onwards, with peaks around the first decades of the 1800s. In a preliminary view, these peaks correspond to a highest frequency of extreme events, with winter as the season of the year with most records.

The basic hypothesis is that extreme seasons correspond to situations in which certain threshold values were exceeded. In historical climatology there is always the problem that this type of data is connected with a huge loss of information compared with instrumental data. Therefore, it is necessary to confirm whether the number of events detected is enough to warrant further analysis. To answer this question we use the concept of binomial random process (Frei and Schär, 2000). The binomial concept considers the number of events at a particular time as the random process consisting of $\mathrm{m}$ independent trials (e.g. total number of seasons in a given period), with probability $\pi$ for a successful trial, e.g. exceeding threshold values. To select the threshold values, a compromise is necessary between values high enough to 
Table 1. Meteorological stations in Andalusia (height expressed in meters above sea level; Period $T=$ period of daily instrumental observations of temperature; Period $R$ : idem for monthly rainfall).

\begin{tabular}{lrrrrr}
\hline Station (Code) & Longitude & Latitude & Height & Period $T$ & Period $R$ \\
\hline Almeria (Al) & $01^{\circ} 23^{\prime} \mathrm{W}$ & $36^{\circ} 51^{\prime} \mathrm{N}$ & 20 & & $1908-2005$ \\
Cadiz (Ca) & $06^{\circ} 20^{\prime} \mathrm{W}$ & $36^{\circ} 45^{\prime} \mathrm{N}$ & 12 & $1851-2005$ & $1821-2005$ \\
Cordoba (Co) & $04^{\circ} 51^{\prime} \mathrm{W}$ & $37^{\circ} 51^{\prime} \mathrm{N}$ & 92 & & $1894-2005$ \\
Gibraltar (Gi) & $05^{\circ} 21^{\prime} \mathrm{W}$ & $36^{\circ} 08^{\prime} \mathrm{N}$ & 8 & & $1813-2005$ \\
Granada (Gr) & $03^{\circ} 37^{\prime} \mathrm{W}$ & $37^{\circ} 08^{\prime} \mathrm{N}$ & 685 & $1893-2005$ & $1898-2005$ \\
Huelva (Hu) & $06^{\circ} 56^{\prime} \mathrm{W}$ & $37^{\circ} 15^{\prime} \mathrm{N}$ & 26 & $1903-2005$ & $1903-2005$ \\
Jaen (Ja) & $03^{\circ} 48^{\prime} \mathrm{W}$ & $37^{\circ} 48^{\prime} \mathrm{N}$ & 484 & & $1867-2005$ \\
Malaga (Ma) & $04^{\circ} 29^{\prime} \mathrm{W}$ & $36^{\circ} 40^{\prime} \mathrm{N}$ & 7 & $1893-2005$ & $1878-2005$ \\
Seville (Se) & $05^{\circ} 53^{\prime} \mathrm{W}$ & $37^{\circ} 25^{\prime} \mathrm{N}$ & 31 & $1893-2005$ & $1865-2005$ \\
\hline
\end{tabular}

focus on tail behavior of the distribution function and threshold values low enough to ensure that a reasonable number of exceedances occur (Solow, 1999). If the threshold values are the percentiles 10 and 90 ( $c_{10}$ and $c_{90}$, respectively), $\pi=\operatorname{Prob}\left\{X<c_{10}\right\}+\operatorname{Prob}\left\{X>c_{90}\right\}=0.20$. These percentiles are commonly used to define the frequency of extreme indices, such as cold nights or warm days, and correspond to moderately extreme events (Zhang et al., 2005). The expected value $\langle n\rangle$ and variance $\operatorname{var}(n)$ of the distribution for $m=31$ are $\langle n\rangle=\pi m=6.2$, and $\operatorname{var}(n)=m \pi(1-\pi)=4.96$, respectively. Similar to Briffa et al. (2002) or Pauling et al. (2006), we use \pm 2 SE to provide an estimate of the uncertainties that are associated with the estimation of the number of extreme seasons. Therefore, we will consider that the total number of extreme seasons is satisfactory when it is included in the interval $\langle n\rangle \pm 2 \sqrt{ } \operatorname{var}(n)=(1.7,10.6)$. The average number of extreme seasons in the case of winter temperatures (since 1780) is 4.3 extreme seasons for each 31-yr period. Mean values of the other seasons of the year are 1.3 for spring, and 1.1 for summer and autumn. In the case of rainfall, the average number of extreme seasons for each 31yr period are 7.6, 7.4, 4.2, and 7.2 for, respectively, winter, spring, summer, and autumn. As a consequence, in the following we will focus our study on winter temperature and seasonal rainfall, and cases of spring, summer, and autumn temperatures will not be considered.

\subsection{Instrumental data}

Instrumental regional series of seasonal temperature and precipitation were obtained from the 19th century to 2005, using the longest available data series in Andalusia (five stations for temperature, since 1851 , and nine stations for rainfall, since 1813, see Table 1). These series, in general terms, coincide with the locations of the documentary data in the pre-instrumental period. All the stations are distributed around $36-37^{\circ} \mathrm{N}$ latitude, and between $1^{\circ}$ and $7^{\circ} \mathrm{W}$ longitude, with different heights above sea level (from Málaga at $7 \mathrm{~m}$ a.s.l. to Granada at $685 \mathrm{~m}$ a.s.1.). Temperature series are from the SDATS database (Spanish Daily Temperature Data, Brunet et al., 2006) and rainfall series were provided by the Spanish Meteorological Agency (http://www.aemet.es) and the British Meteorological Office in the case of Gibraltar (Wheeler, 2007). All of them are high quality series, without homogeneity problems (Almarza et al., 1996). Local monthly rainfall totals were used to obtain seasonal total rainfall. The regional series was obtained for each season by averaging the corresponding local values, and considering in each year the number of stations with data. This procedure was followed because a common period would be too short (since 1903 for temperatures and 1908 for rainfall), removing from the instrumental series the period 18851915, which was considered as reference period (see below). This procedure does not substantially bias the results. Table 2 shows the statistics corresponding to the reference period 1960-1990. The construction of a regional series is justified by the analysis of the spatio-temporal variability in the region. The application of empirical orthogonal function (EOF) analysis to Andalusian stations during the period 1867-2003 (Castro-Díez et al., 2007) showed that, at seasonal and annual timescales, the first leading EOF pattern (explaining more than $50 \%$ of the variance for both, temperature and precipitation) presents high correlations with all the stations, particularly in winter $(65.69 \%$ of explained variance for precipitation, $72.56 \%$ for temperature). Basic statistics correspond to Mediterranean climatic characteristics, with wet and mild winters, warm and dry summers, and spring and autumn as transition seasons. A season may be characterized as dry (cold) if total rainfall (average temperature) is lower than the 10th or 25th percentile of the reference period ( $c_{10}$ and $c_{25}$, respectively). Similarly, a season was considered as wet (warm) if total rainfall (average temperature) was higher than the 75th or 90th percentile of the reference period ( $c_{75}$ and $c_{90}$, respectively). These percentiles are currently used to characterize very dry, dry, rainy and very rainy seasons in Spain (García de Pedraza and García Vega, 1989). The Kolmogorov-Smirnov test (Wilks, 1995) 
Table 2. Main statistics of the seasonal regional series for temperature $\left(T\right.$ in $\left.{ }^{\circ} \mathrm{C}\right)$ and precipitation $(R$ in $\mathrm{mm})$ for the reference period 1960-1990 ( $u=$ mean value; $s=$ standard deviation; $c_{i}=\mathrm{i}$-th percentile; $\mathrm{KS}=$ Kolmogorov-Smirnov statistic, in bold if the hypothesis of conforming to a normal distribution is not rejected at the $95 \%$ confidence level $\mathrm{KS}<0.161$ for $N=30$ (Wilks, 1995).

\begin{tabular}{lllll}
\hline Parameter & Winter & Spring & Summer & Autumn \\
\hline$u(T)$ & 11.0 & 15.5 & 23.9 & 18.5 \\
$s(T)$ & 0.8 & 0.8 & 0.7 & 1.0 \\
$c_{10}(T)$ & 10.0 & 14.6 & 23.1 & 17.3 \\
$c_{25}(T)$ & 10.4 & 15.0 & 23.7 & 17.8 \\
$c_{75}(T)$ & 11.6 & 16.1 & 24.3 & 18.9 \\
$c_{90}(T)$ & 12.0 & 16.6 & 24.6 & 19.8 \\
$\mathrm{KS}(T)$ & $\mathbf{0 . 0 7 8}$ & $\mathbf{0 . 0 8 8}$ & $\mathbf{0 . 1 4 9}$ & $\mathbf{0 . 1 0 6}$ \\
$u(R)$ & 224.2 & 128.8 & 22.8 & 162.3 \\
$s(R)$ & 111.1 & 56.8 & 12.3 & 86.4 \\
$c_{10}(R)$ & 111.0 & 70.4 & 10.3 & 56.9 \\
$c_{25}(R)$ & 147.1 & 87.1 & 14.1 & 87.0 \\
$c_{75}(R)$ & 271.1 & 155.3 & 24.9 & 212.7 \\
$c_{90}(R)$ & 381.5 & 197.0 & 37.6 & 263.5 \\
$\mathrm{KS}(R)$ & $\mathbf{0 . 1 2 4}$ & $\mathbf{0 . 1 1 8}$ & 0.182 & $\mathbf{0 . 1 0 6}$ \\
\hline
\end{tabular}

was applied to test the normality of the distribution. It was seen that there is not enough evidence to prove that the distribution is not normal, at a $95 \%$ confidence level, except in the case of summer rainfall.

\subsection{Simulated climate in Andalusia}

A climate simulation was used to test some aspects of the methodology and to evaluate the magnitude of the uncertainties of the methodology, as further discussed in the next section. The simulation covers the IP with a spatial resolution of $30 \mathrm{~km}$ during the period 1001-1990. It was performed with a climate version of the regional model MM5, and was driven through the domain boundaries by a simulation performed with the Global Circulation Model ECHO-G (Zorita et al., 2005). Both simulations consider variations in three main external factors: concentration of greenhouse gases, total solar irradiance at the top of the atmosphere, and the effect of large volcanic events. These factors behave in the simulation according to the reconstruction by Crowley (2000). This simulation has demonstrated to simulate realistically many aspects of the climate of the IP in the recent past, where there are reliable data and observations to compare with, and significantly improves the accuracy of the simulation performed with the global model alone. The reader is referred to Gómez-Navarro et al. (2011) for a technical description and validation of this simulation. The present article focuses on the simulated seasonal means of temperature and rainfall regionally averaged over Andalusia.

\section{Methodology}

The reconstruction methodology used was explained in Rodrigo (2008). The basic ideas are the following:

Hypothesis 1: past extreme events may be defined in a similar way to present events; that is, we assume that threshold values of the reference period were exceeded when there was an extreme event in the past.

The starting point of the study consists of simply estimating the frequency of extreme seasons in past periods. A season is considered extreme if documentary data provides information on the occurrence of extreme events during the corresponding months (heat waves, snowfalls, frosts, intense and/or continuous rainfall, floods, droughts). The length of the periods considered is $31 \mathrm{yr}$, which allows comparison with the modern reference period. In this way, the numbers $n_{1}$ and $\mathrm{n}_{\mathrm{h}}$ of, respectively, dry or cold, and wet or warm seasons within a given 31-yr period may be established.

If $F_{X}$ is the distribution function representative of the climate variable (in our case, seasonal average temperature and rainfall), the quantiles $q_{1}$ and $q_{\mathrm{h}}$ of the distribution function, corresponding to dry/cold and wet/warm seasons, respectively, may be found as

$$
\begin{aligned}
\frac{n_{1}}{n} & =\operatorname{Prob}\left\{X \leq q_{1}\right\}=F_{X}\left(q_{1}\right) \rightarrow q_{1}=F_{x}^{-1}\left(q_{1}\right) \\
\frac{n_{\mathrm{h}}}{n} & =\operatorname{Prob}\left\{X>q_{\mathrm{h}}\right\}=\operatorname{Prob}\left\{X \leq q_{\mathrm{h}}\right\} \\
& =1-F_{X}\left(g_{\mathrm{h}}\right) \rightarrow g_{\mathrm{h}}=F_{X}^{-1}\left(1-\frac{n_{\mathrm{h}}}{n}\right)
\end{aligned}
$$

where $\mathrm{n}$ is the total number of seasons in the chosen period (in our case, $n=31$ ).

Hypothesis 2: the distribution function representative of the climatic variable is the standardized normal distribution of mean 0 and standard deviation 1 , that is $F_{X}=N(0 ; 1)$.

The normal distribution function is the simplest choice, bearing in mind that the regional series of temperature and precipitation are obtained as the average value of the individual series. For the time scales at which we are working, the precipitation amounts tend to be more closely approximated as the normal distribution because of the central limit theorem, which states that under fairly general conditions, the sum of independent variables approaches the normal distribution (Lettenmaier, 1995). This hypothesis, in the case of Andalusian rainfall, is valid for all the seasons of the year, except summer (Rodrigo, 2002), and it was tested for the instrumental regional series of the reference period (Table 2).

The quantiles of the series may be established using $c=u$ $+s q$, where $u$ is the mean value, $s$ the standard deviation, $c$ the quantile of the non-standardized normal distribution $N(u, s)$, and $q$ the quantile of the $N(0 ; 1)$. Therefore,

$c_{1}=u+s q_{1} c_{\mathrm{h}}=u+s q_{\mathrm{h}}$

If we know the values of the $c$ quantiles, then we have a two equation system with two unknown variables, $u$ and $s$. The 
mean value $u$ and standard deviation $s$ of a given period may be found as

$u=c_{\mathrm{h}}-s q_{\mathrm{h}}=c_{1}-s q_{1}$.

Summarizing, for each 31-yr period, from documentary data analysis, $\mathrm{n}_{1}$ and $\mathrm{n}_{\mathrm{h}}$ are calculated. These numbers are used to estimate $q_{\mathrm{l}}$ and $q_{\mathrm{h}}$, and the $s$ and $u$ values are estimated considering the values of $c_{\mathrm{l}}$ and $c_{\mathrm{h}}$ corresponding to the reference period.

The advantages of this method are that it reduces possible subjectivity problems (due to the documentary source, or the researcher) associated with the assignment of ordinal indices to quantify documentary data, and it does not need an overlapping period with instrumental data to obtain quantitative estimates of the climate variables in the past. Changes in the mean value and/or in the standard deviation will yield changes in the probability of extreme events, and, therefore, in the frequency of these events. Our aim is to study the inverse problem, that is, infer changes in mean and standard deviation from the frequency of extreme events, keeping in mind that documentary data basically reflect the occurrence of extreme events and their impacts.

The application of this method is only possible if we have sufficient data to accomplish the different steps. In fact, if $n_{1}=0$, then $q_{1} \rightarrow-\infty$, and if $n_{\mathrm{h}}=0$, then $q_{\mathrm{h}} \rightarrow$ $\infty$. Therefore, the absence of information on extremes in certain periods implies the appearance of gaps in the reconstructed series.

This methodology can be tested within the context of the pseudoreality of the climate simulation. The underlying idea is that even if the evolution of the simulation does not perfectly match the real evolution of the climate in the past millennium, it represents a feasible evolution of the climate since it is physically self-consistent. Thus, the statistical properties of the simulated variables, and their physical relationships, are a reliable version of the actual ones. An obvious advantage of using a climate model is that within the simulation the information is available at all temporal and spatial scales. Thus, one can construct a pseudoproxy inside the model for a given variable, apply the reconstruction methodology to be tested and generate a pseudoreconstruction. This can be later compared with the simulated evolution of the variable, which is known. It is important to note that this exercise does not validate the model, but the methodology used to reconstruct the actual climate.

The procedure to create the pseudoproxy is as follows. A reference period has to be chosen, as well as a probability threshold, to define what an extreme event is. Once this is fixed, the $c_{\mathrm{h}}$ and $c_{1}$ values can be found. The next step is to compare the simulated seasonal means with these percentiles to obtain a series of $0 \mathrm{~s}$ and $1 \mathrm{~s}$ representing the occurrence or not of an extreme season. Using a running window of $31 \mathrm{yr}$, the number of extreme seasons in a given period, $n_{1}$ and $n_{\mathrm{h}}$, can be estimated, which are the pseudoproxy.
Table 3. Statistics of the reconstruction method when applied to all the simulated series of mean value $(u)$ and standard deviation $(s)$ of winter temperature $\left(T\right.$, in $\left.{ }^{\circ} \mathrm{C}\right)$ and rainfall $(R$, in mm) shown in Figs. 3 and 4. Shown are the Root Mean Square Error (RMSE), the Nash-Sutcliffe index (NSI), the correlation (Corr) and the percentage of gaps (\% gaps) in the reconstruction. Bold numbers in correlation denotes statistically significant at the $95 \%$ confidence level.

\begin{tabular}{lrrrr}
\hline $\begin{array}{l}\text { Variable/Period/ } \\
\text { Percentile }\end{array}$ & RMSE & NSI & Corr. & \% gaps \\
\hline$u(T) / 1900 / 10-90$ & 0.12 & 0.81 & $\mathbf{0 . 9 2}$ & 22.37 \\
$u(T) / 1900 / 25-75$ & 0.084 & 0.92 & $\mathbf{0 . 9 7}$ & 2.84 \\
$u(T) / 1975 / 10-90$ & 0.18 & 0.56 & $\mathbf{0 . 9 0}$ & 62.71 \\
$u(T) / 1975 / 25-75$ & 0.24 & 0.16 & $\mathbf{0 . 8 6}$ & 33.19 \\
$u(R) / 1900 / 10-90$ & 15.19 & 0.17 & $\mathbf{0 . 8 6}$ & 7.77 \\
$u(R) / 1900 / 25-75$ & 12.21 & 0.61 & $\mathbf{0 . 9 5}$ & 0 \\
$u(R) / 1975 / 10-90$ & 14.0 & 0.44 & $\mathbf{0 . 8 5}$ & 11.34 \\
$u(R) / 1975 / 25-75$ & 9.02 & 0.79 & $\mathbf{0 . 9 5}$ & 0 \\
$s(T) / 1900 / 10-90$ & 0.11 & 0.0 & $\mathbf{0 . 7 5}$ & 22.48 \\
$s(T) / 1900 / 25-75$ & 0.16 & -0.95 & $\mathbf{0 . 6 7}$ & 3.04 \\
$s(T) / 1975 / 10-90$ & 0.19 & -1.36 & $\mathbf{0 . 6 1}$ & 62.71 \\
$s(T) / 1975 / 25-75$ & 0.27 & -4.15 & $\mathbf{0 . 4 1}$ & 33.19 \\
$s(R) / 1900 / 10-90$ & 13.75 & -0.44 & $\mathbf{0 . 3 2}$ & 7.77 \\
$s(R) / 1900 / 25-75$ & 21.01 & -0.44 & 0.14 & 0 \\
$s(R) / 1975 / 10-90$ & 16.35 & -1.42 & $\mathbf{0 . 3 0}$ & 11.34 \\
$s(R) / 1975 / 25-75$ & 17.72 & -1.12 & 0.18 & 0 \\
\hline
\end{tabular}

An important drawback of applying the above methodology is that a reference period, as well as a probability threshold to define an event extreme, has to be arbitrarily defined. The reconstruction methodology is in principle sensitive to this choice, introducing an uncertainty factor which is important to assess. Four different combinations have been tested in the present study: two reference periods (the 31-year periods 1885-1915 and 1960-1990) with two pairs of probability thresholds (percentiles $10-90$ and 25-75), receptively. The period 1885-1915 was chosen because a priori it is markedly different from the modern period 1960-1990, and it is expected that the effects of global warming would have been of less importance during these years (it is a transition period between the end of the Little Ice Age and the modern warming period). This exercise was applied to the simulated winter mean series of temperature and precipitation (the results for other seasons are similar, and are not shown) to reconstruct the simulated evolution of these variables during the last millennium.

Figure 3 represents the evolution of the 31-yr running means of temperature and precipitation in the simulation, together with the four tested pseudoreconstructions. The black line in the upper (lower) panels represents the running mean of the evolution of temperature (precipitation). For each variable, two periods have been used as reference (1885-1915 and 1960-1990), as well as two sets of percentiles (10-90 

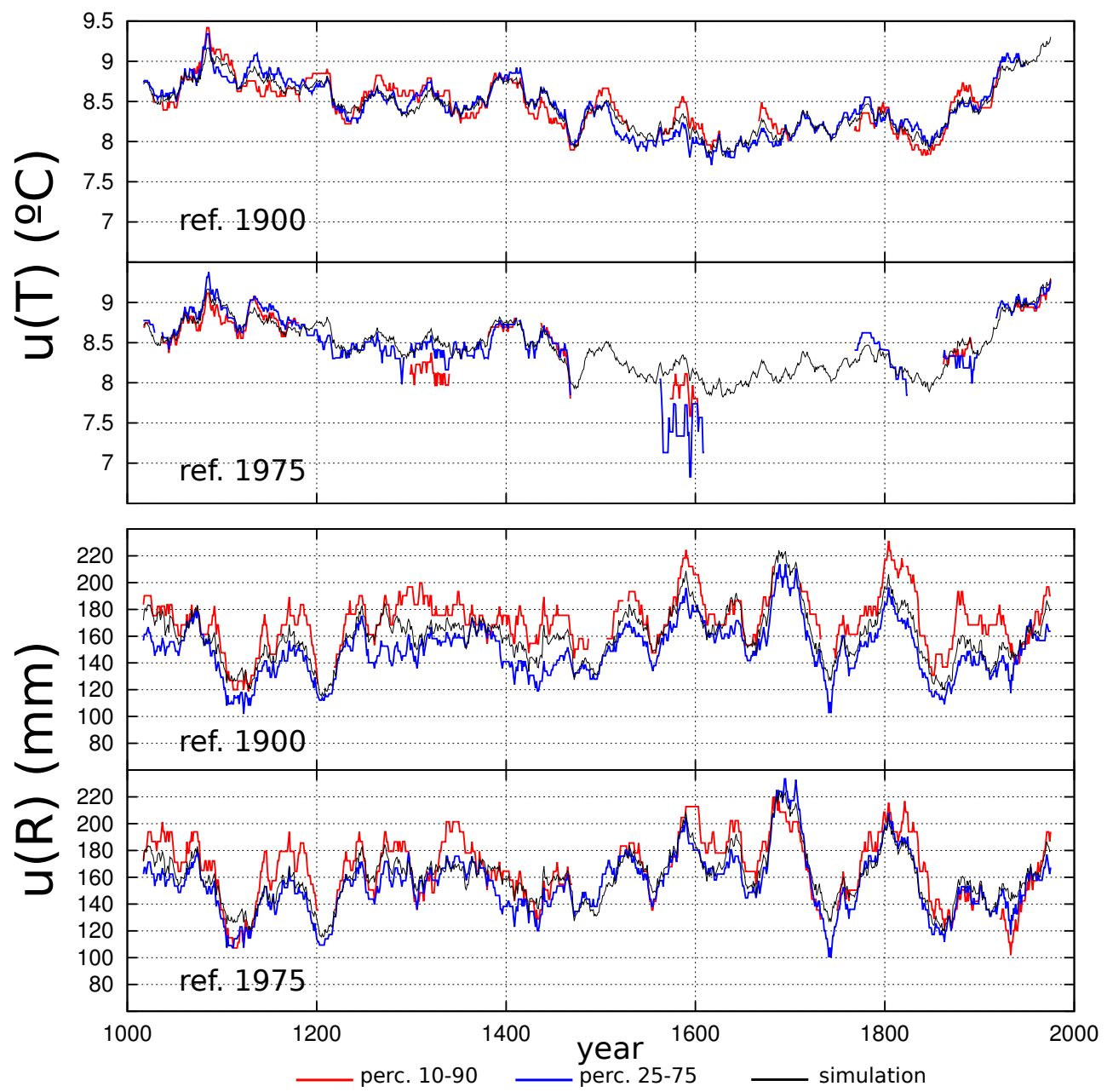

Fig. 3. Evolution (in black) of the 31-yr running mean of temperature (two upper panels) and precipitation (two lower panels) in the climate simulation for the last millennium. Four pseudoreconstructions are shown, using the periods 1885-1925 (first and third panels) and 19601990 (second and fourth panels) using the 10-90 (red lines) and 25-75 (blue lines) percentiles.

and $25-75$, in red and blue, respectively). Overall, there is a good agreement between the original and reconstructed series, although it is slightly better when the larger percentiles are used. This is a statistical problem linked to the ability of a set of only 31 elements to sample the tails of the normal distribution. More importantly, there are several gaps in the pseudoreconstructions, which occur when no extreme events are registered in the window, as discussed above. The gaps are especially noticeable for temperature and when the period 1960-1990 is used as reference. This is again a sampling problem, due to the large differences between the mean temperatures in this warm reference period and other colder periods of the past in the simulation. Similarly, Fig. 4 represents the same as Fig. 3 for the reconstructions of standard deviation. In this case the agreement is worse, although the order of magnitude is correct. As before, there are some gaps, especially for temperature when the 1960-1990 period is chosen as reference.
A quantitative analysis of the capabilities of the methodology is shown in Table 3. Several statistics have been calculated for all the pseudoreconstructions shown in Figs. 3 and 4. The Root Mean Square Error (RMSE) is depicted in first column. It varies among the four tested reconstructions, ranging from 0.1 to $0.2^{\circ} \mathrm{C}$ in mean temperature, and from 9.0 to $15.2 \mathrm{~mm}$ in mean precipitation. Similarly, the standard deviation reconstructions vary from 0.1 to $0.3^{\circ} \mathrm{C}$ and from 13.8 to $21.0 \mathrm{~mm}$ in temperature and precipitation, respectively. However, there is no clear relationship between a lower RMSE and the chosen period or percentile. The mean value of the RMSE in the four pseudoreconstructions can be considered as a measure of the uncertainty in the methodology due to the arbitrary choice of the references, and it is hereafter used as the uncertainty bar when reconstructing the actual climate (shadow in Figs. 5, 6, 7 and 8). The NashSutcliffe model efficiency index (NSI) is shown in second column. It consists of a dimensionless index, in the range 

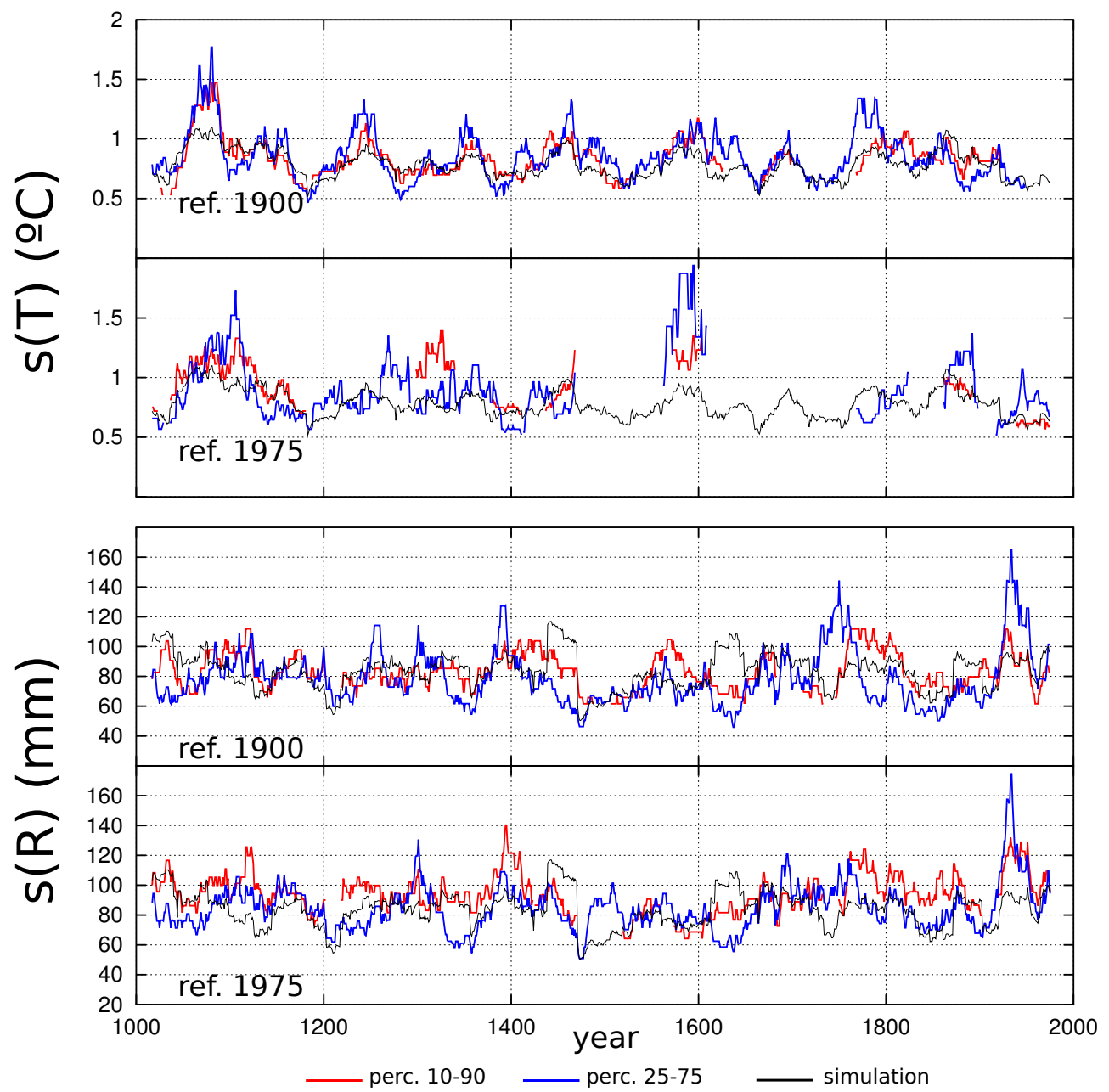

Fig. 4. As Fig. 3 for standard deviation.

[-infinite,1] commonly used to test the skill of forecast models (Nash and Sutcliffe, 1970). It measures the capability of the model to fit to a given set of observations compared with the mean value of these observations. A value of 1 implies that the fit between model and observations is perfect. Values greater than 0 imply that model is better than the mean. However, negative values mean that the model does worse than a constant value equal to the average of the observations. The method has demonstrated being capable to reconstruct with good skill the mean in all cases, although in general terms reconstructions for temperature are better achieved than for rainfall. Nevertheless, reconstructions of standard deviation perform worse. In all cases the index is negative, indicating that the methodology is not capable to outperform a climatological value. Correlation between simulated and reconstructed series is shown in third column. Bold numbers denote statistically significant correlation at the $95 \%$ confidence level. This level was estimated using a numerical bootstrap method (Ebisuzaki, 1997) which does take into account the autocorrelation of the original series. For mean values, correlations are above 0.85 and are significant in all cases. However, for standard deviation the skill is lower (as already identified by using the NSI index), and in two cases the correlation is not significant. Finally, the percentage of gaps in the pseudoreconstructions are shown in last column. It is larger for temperature when the reference period is chosen around 1975 , as discussed above.

\section{Reconstruction}

The methodology explained in the previous section was applied to the number of extreme seasons observed in the documentary data for winter temperature and winter, spring and autumn rainfall (the normality hypothesis is not valid for summer rainfall). The procedure was applied to consecutive periods with a running window of $31 \mathrm{yr}$, the first one being 1774-1804, the second 1775-1805, until the last $31-\mathrm{yr}$ period $1820-1850$ for temperature (1701$1731,1702-1732, \ldots, 1820-1850$ for rainfall). Therefore, the 

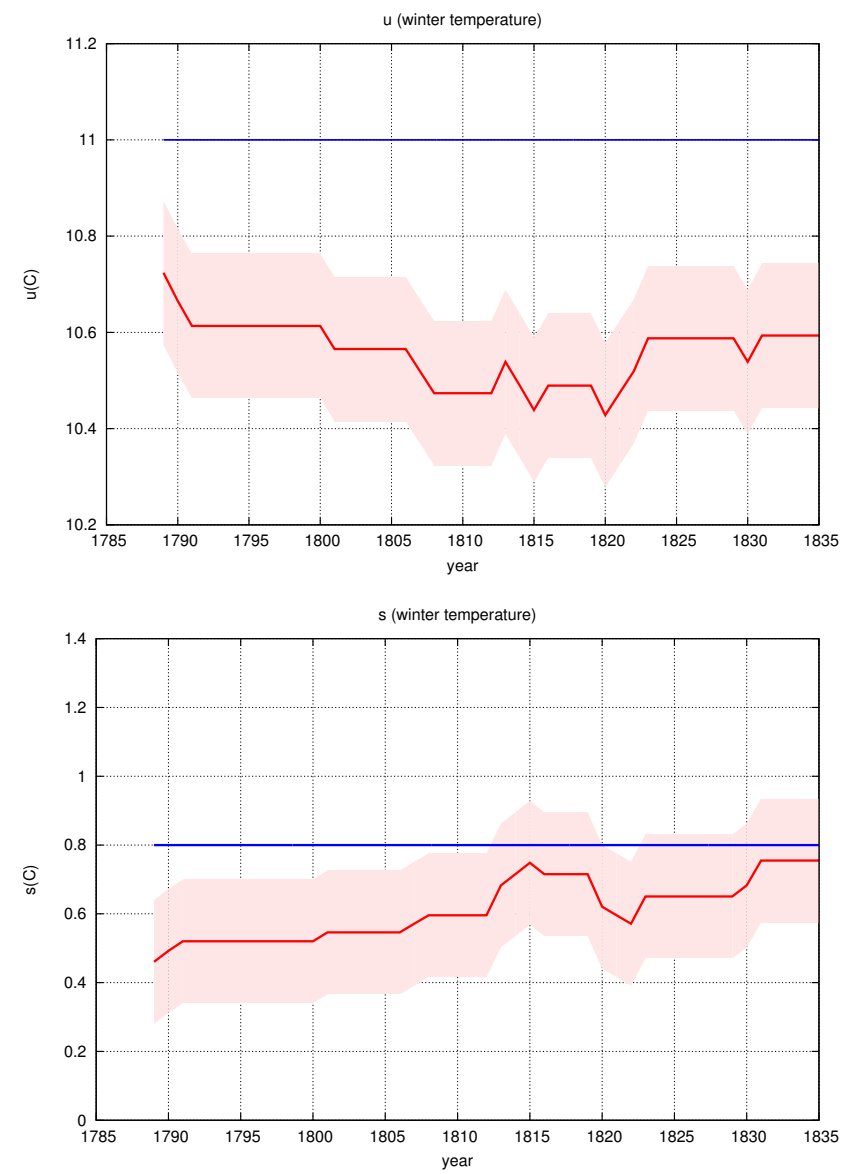

Fig. 5. Reconstruction of mean value (top), and standard deviation (bottom) of winter temperature for 31-yr running periods. The shadowed area represents the uncertainty range estimated using the model simulations for the whole millennium. Blue horizontal line: value corresponding to the reference period 1960-1990.

reconstruction yields the 31-yr running means and standard deviations. Four reconstructions were initially made using two reference periods and two pair of threshold values $c$. The reference periods chosen were 1885-1915 and 1960-1990. For each variable, a t-test for difference between means, an F-test for variances ratio, and a Kolmogorov-Smirnov test were performed to compare periods. The period 1885-1915 was significantly cooler in winter and wetter in spring and autumn (Table 4). For each reference period, two reconstructions were made, using as threshold values $c_{1}$ and $c_{\mathrm{h}}$, the percentiles 10 and 90 , and 25 and 75, respectively. Table 4 shows that these values may be very different, although there are no significant differences between periods (as, for instance, in the case of winter rainfall). The definitive reconstruction was obtained as the ensemble of the four individual reconstructions, and the associated uncertainty was estimated from the model simulations.
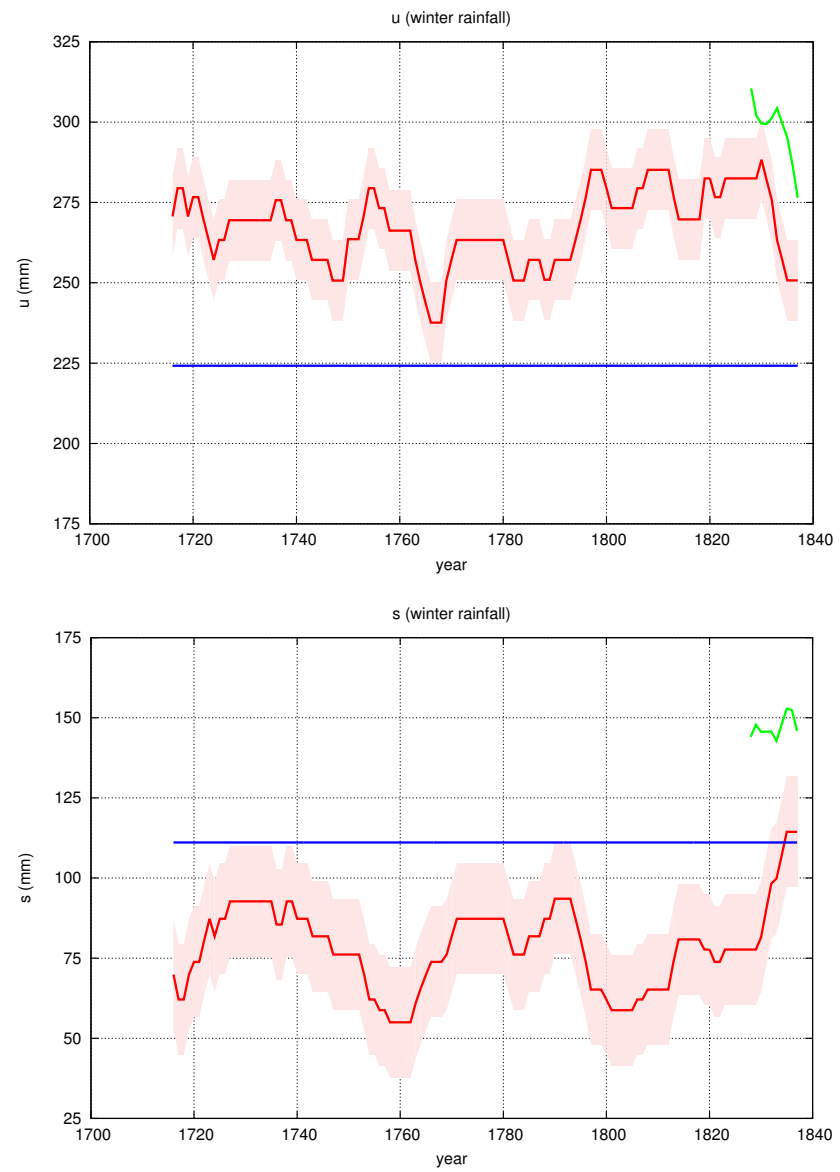

Fig. 6. As Fig. 5, for winter rainfall (green line: instrumental running means).

The methodology allows low-frequency changes in the climate variables to be reconstructed. Nevertheless, as will be seen below, it is possible to obtain high-frequency variability (interannual time-scale) when there is no gap between reconstructed and instrumental series.

Figure 5 shows the results corresponding to winter temperature for mean value $u$ (top) and standard deviation $s$ (bottom), with the uncertainty bands determined by the RMSE within the model. Blue horizontal continuous lines indicate the value corresponding to the reference period 1960-1990. First, it may be seen that mean temperatures were slightly lower (up to $0.5^{\circ} \mathrm{C}$ ) than the modern value, with a minimum around 1815 and 1820 . In the second place, the variability of winter temperatures is slightly lower than that of the reference period, although it slightly increases to reach a peak around the same time interval, and at the end of the reconstructed period. The last result is yielded by the increasing number of observations at the end of the record.

Figures 6 to 8 show the reconstructions for winter, spring, and autumn rainfall, respectively. In these cases, there is an overlapping period with instrumental data (green line) but the overlapping period is too brief to obtain statistical 
Table 4. Main statistics of the reference period 1885-1915 (Twi = winter temperature $\left({ }^{\circ} \mathrm{C}\right)$; Rwi $=$ winter rainfall $(\mathrm{mm})$; Rsp $=\operatorname{spring}$ rainfall $(\mathrm{mm}) ; \mathrm{Rau}=$ autumn rainfall $(\mathrm{mm}) ; u=$ mean value; $s=$ standard-deviation; $\mathrm{ci}=\mathrm{i}$-th percentile) and comparison with the period 1960-1990 (t-test, in parenthesis confidence interval for difference between means at the $95 \%$ confidence level; F-test, in parenthesis confidence interval for variances ratio at the $95 \%$ confidence level; KS $=$ Kolmogorov-Smirnov statistic, in bold differences significant at the $95 \%$ confidence level).

\begin{tabular}{|c|c|c|c|c|}
\hline \multicolumn{5}{|c|}{ 1885-1915 } \\
\hline & Twi & Rwi & Rsp & Rau \\
\hline$u$ & 10.6 & 228.3 & 190.1 & 210.9 \\
\hline$s$ & 0.7 & 102.7 & 75.9 & 70.4 \\
\hline$c 10$ & 9.8 & 121.9 & 88.4 & 126.8 \\
\hline$c 25$ & 9.9 & 154.4 & 132.2 & 174.9 \\
\hline$c 75$ & 11.1 & 289.7 & 239.4 & 248.3 \\
\hline$c 90$ & 11.5 & 332.4 & 282.2 & 299.0 \\
\hline \multicolumn{5}{|c|}{ Comparison between 1885-1915 and 1960-1990 } \\
\hline & Twi & Rwi & Rsp & Rau \\
\hline t-test & $2.45(0.09,0.887)$ & $0.16(-58.5,50.3)$ & $3.60(-95.3,-27.2)$ & $2.43(-88.6,-8.5)$ \\
\hline F-test & $1.10(0.5,2.3)$ & $1.17(0.56,2.43)$ & $1.78(0.86,3.70)$ & $1.51(0.72,3.13)$ \\
\hline KS & 0.2581 & 0.0968 & 0.4194 & 0.3871 \\
\hline
\end{tabular}

correlations. In all cases, the standard deviation reconstructed is lower than that of the reference period 1960-1990, except at the end of the series, probably as a consequence of the loss of variance in proxy data compared with instrumental data. In the case of winter rainfall, the mean value of the complete period $1701-1850(267 \pm 18 \mathrm{~mm})$ was $19 \%$ higher than during the reference period 1960-1990. The reconstructed values show minima around 1750, 1770, and 1790, an increase of rainfall in the first decades of the 19th century, and decreasing rainfalls at the end of the series. Comparison with contemporary instrumental running means at the end of the record shows that the magnitude of reconstructions is similar to instrumental values. In this case, it must be borne in mind that instrumental values correspond mainly to Gibraltar, which is noticeably wetter than nearby sites in mainland Spain (Wheeler, 2007).

Figure 7 shows the reconstruction corresponding to spring rainfall. The gap corresponding to the first years of the 19th century is due to the absence of information on droughts $\left(n_{1}=0\right)$ from 1790 to 1824 . The mean value for the complete period $(164 \pm 11 \mathrm{~mm})$ was $27 \%$ higher than during the reference period 1960-1990. The results show a dry period approximately between 1730 and 1790, with an increase of spring rainfall in the last decade of the 18th century and first decades of the 19th century. Comparison with contemporary instrumental running means shows that reconstruction slightly overestimates the instrumental values.

Figure 8 shows the reconstruction corresponding to autumn rainfall. The gap corresponds to the absence of information on droughts from 1782 to $1826\left(n_{1}=0\right)$. The mean value for the complete period 1701-1850 (194 $\pm 16 \mathrm{~mm})$ was
$19 \%$ higher than during the reference period 1960-1990. The behavior of autumn rainfall is very similar to spring rainfall, with a minimum in the period centered around the $1760 \mathrm{~s}$, and a progressive increase of precipitation from 1790s onwards. Again, the reconstruction clearly overestimates instrumental values. A possible explanation lies in the character of rainfall during this season of the year, with an important role of convective precipitation, that is, intense, short duration, local rainfall. In consequence, it may be the result of assigning an extreme character to the seasonal regional series when the event was strictly local, and limited to a few hours a day. A possible solution to this problem would be to refine the spatiotemporal resolution of the study, at least at the monthly time scale and for individual localities.

\section{Discussion}

The best way to confirm these results is to see whether other evidence corresponding to other proxy data or data from neighbouring regions presents similar characteristics. To date, there have been few attempts to reconstruct temperatures over time in the IP due to the scarcity of information, the exception being the works by Rodrigo et al. (1998) and Bullón (2008) focusing on Castile, in the central area of the IP, and for brief time periods (1634-1648, and 1550-1599, respectively). Our work represents the first attempt to reconstruct temperatures in the study region. The most noteworthy events during the period analyzed were the occurrence of snowfalls and frosts in localities where these events are very rare, such as Cadiz (frosts at dawn on 10 to 12 February 1803 , 

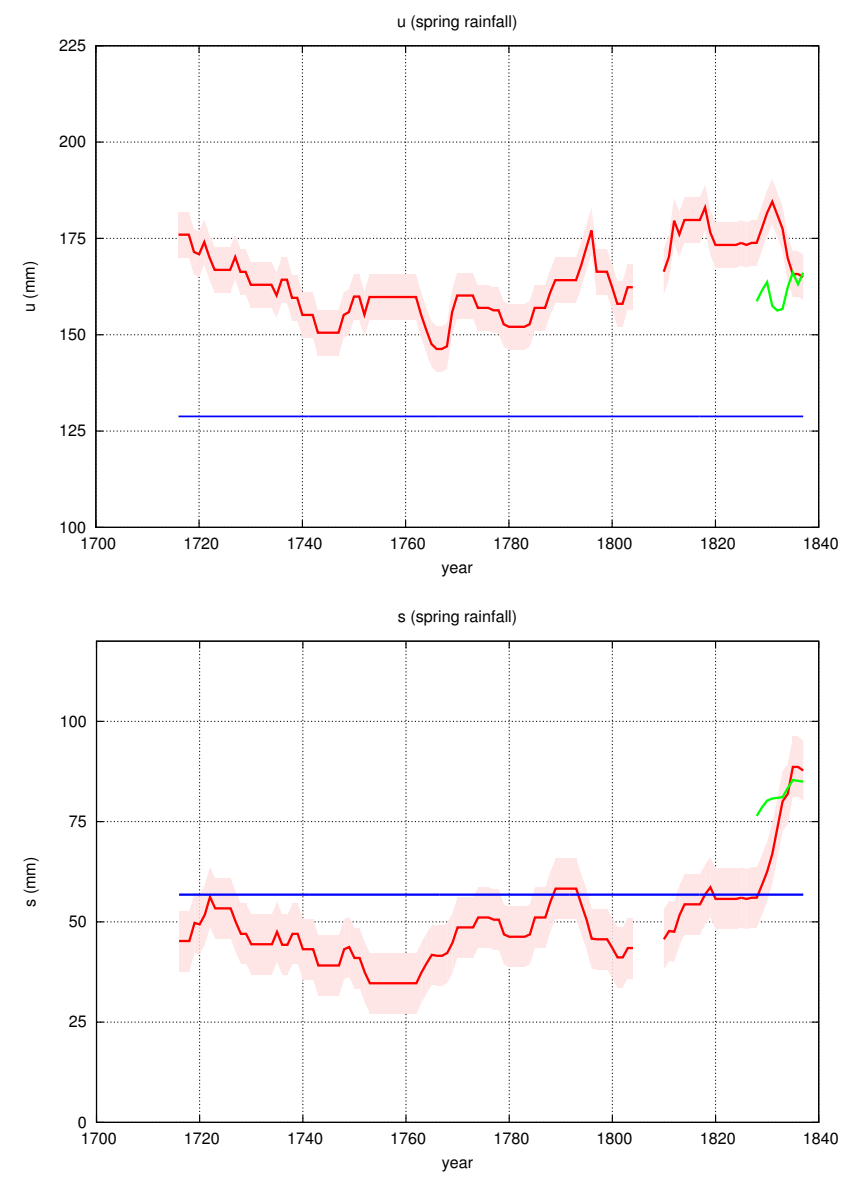

Fig. 7. As Fig. 6 for spring rainfall.

snowfalls on 12 January 1820), the Mediterranean coast (snowfalls in Motril on 19 January 1816, frosts in Almuñecar on 10-11 January 1830, frost in Malaga on 12 January 1850), and Seville (frosts on February 1822, 1823, and December 1846, snowfalls on 7 February 1819 and February 1845). In addition, early instrumental data for Cadiz have allowed a first approach to the evolution of temperature in the region. As regards winter temperature, Wheeler (1995) found that winter temperatures of Cadiz from 1789 to 1816 were about $0.6^{\circ} \mathrm{C}$ lower than modern data, a result similar to our reconstruction. Gallego et al. (2007) found that sunset temperatures taken in Cadiz for 1825-1852 show values as much as $2.7^{\circ} \mathrm{C}$ lower relative to the 1971-2000 period from December to February. On the other hand, although it seems that the impact of the Tambora eruption on Iberia was more important in summer (Trigo et al., 2009), a minimum in winter temperature has been detected around 1815-1820. Diodato et al. (2010) also found low temperatures in their reconstruction of winter temperatures in central-southern Italy during the first decades of the 19th century. The analysis of early instrumental data in the region is a work in progress, but the first results seem to confirm, at least qualitatively, the validity of our reconstruction.
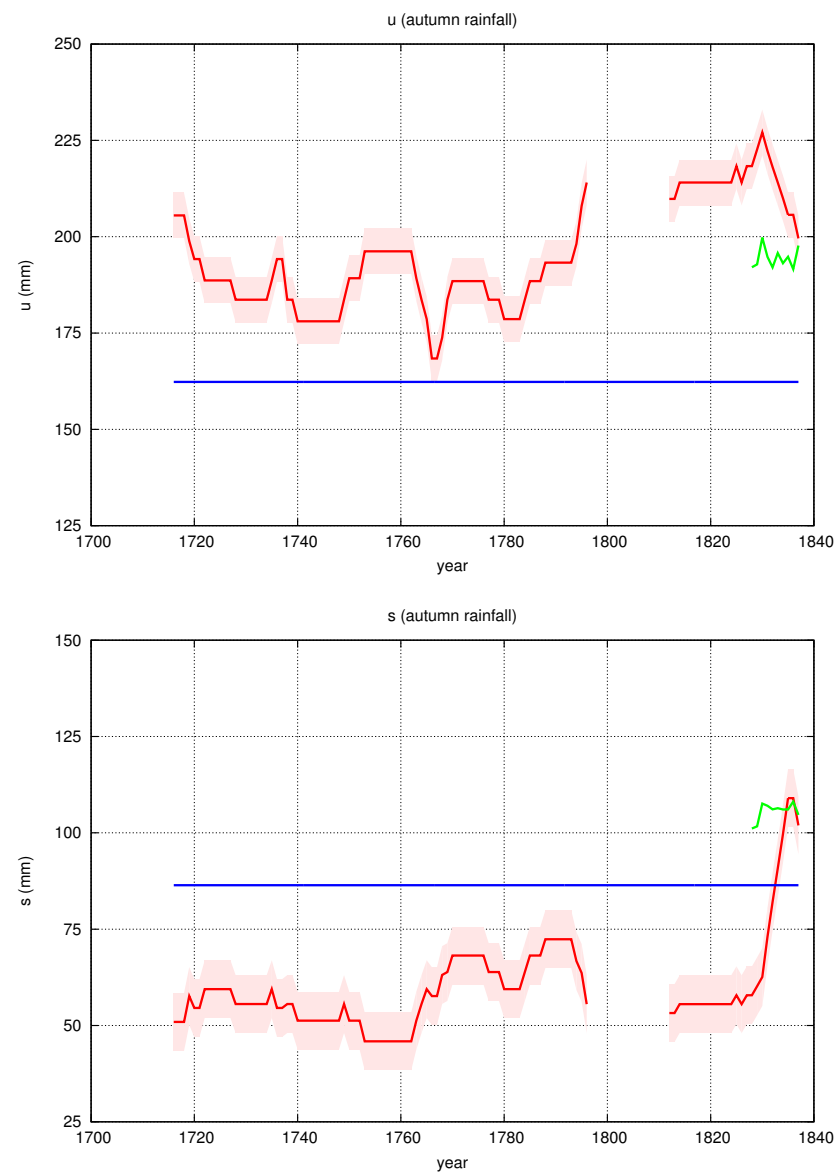

Fig. 8. As Fig. 6 for autumn rainfall.

The organization of religious ceremonies (rogations) by municipal and ecclesiastic authorities in response to climatic factors that altered the usual development of the principal crops allows the reconstruction of variations in precipitation, the principal conditioning factor of cereal production in the Mediterranean climate (Martín-Vide and Barriendos, 1995). The compilation of series of pro serenitate (excess of precipitation that produced flooding) and pro pluvia (droughts) rogations has allowed the reconstruction of rainfall fluctuations (Rodrigo and Barriendos, 2008), and the time series of floods (Barriendos and Rodrigo, 2006) and droughts (DomínguezCastro et al., 2010) in the IP. This information can be converted into monthly climatic indices by assigning an ordinal index to the months with rogations ( +1 to pro serenitate, -1 to pro pluvia rogations, 0 to lack of information or absence of extreme events). Seasonal indices are obtained as the sum of the corresponding monthly indices, ranging from -3 to +3 . The rogation series corresponding to Seville were not used in our reconstruction, but was reserved to compare with our results. However, we must remember that rogation series are local, whereas our reconstruction is regional. The methodology used reconstructs 31-yr running means, not annual 
values. Therefore, we must convert the mean values obtained into annual values. Running means may be expressed as

$u_{t}=\frac{1}{2 r+1} \sum_{k=-r}^{k=r} x_{t}+k$

where $x$ is the annual value, and $2 r+1=n(n=31, r=15$ in our case). As a consequence, considering two consecutive running means, we obtain

$x_{t-r}=x_{t+r+1}--n\left(u_{t+1}-u_{t}\right)$

In this way, it is possible to obtain past annual values by means of an iterative process using instrumental values and running means. One inconvenience of this method is that the presence of gaps (in instrumental series or running means) propagates backward, preventing a complete reconstruction. This methodology was used for the winter and spring rainfall series (the number of gaps in autumn was very high), considering that the instrumental series began in 1821 , so that the first instrumental running mean is centered on 1836. Therefore, annual values were obtained from 1701 to 1820 . Figure 9 shows the comparison of the annual values obtained $(z$, expressed as standardized anomalies relative to the reference period 1960-1990) with the index series from rogations in Seville ( $I$ ) for winter (a) and spring (b) during the same time period. Correlation coefficients are significant at the $95 \%$ confidence level, but not very high $(r=0.30)$, due to various factors: the I series are local, while the $\mathrm{z}$ series are regional; the existence of gaps in the instrumental series $(1833,1834$, 1836, and 1837 in winter; $1824,1825,1833,1836$, and 1837 in spring) and the $u$ series for spring (1805-1809, Fig. 7) multiply the number of gaps in past - in total, $16(13.3 \%)$ in winter and $34(28.3 \%)$ in spring - and the absence of information on rogations led us to assign an index value $I=0$ in years in which the reconstruction shows positive and negative anomalies (for instance at the beginning of the 18th century in spring). However, at least from a qualitative point of view, the coincidence of positive and negative values is clear. Positive values are detected, for example, in 1708, 1768, 1784, or 1808 (winter), and 1736, 1772, 1786 and 1804 (spring). Frequent droughts are found in 1737, 1753, 1789, and 1808 (winter), and 1722, 1737, 1750, 1780, and 1813 (spring). Indices obtained for southern Portugal for the 18th century (Taborda et al., 2004) also show positive values in 1708 and 1784 (winter), 1736 and 1786 (spring), and frequent droughts in winter 1737 and 1753.

Rogation ceremonies and rainfall information contained in documentary data are directly related to the behavior of crops, mainly wheat and barley. There is another important data source related to agricultural production: harvest taxes, or tithes. Every producer or owner had to pay $10 \%$ of the total production either in kind or in money, after a public auction. This proxy was used to reconstruct precipitation in the Canary Islands for the period 1595-1836 (García et al., 2003). In Andalusia, a great number of tithes series have
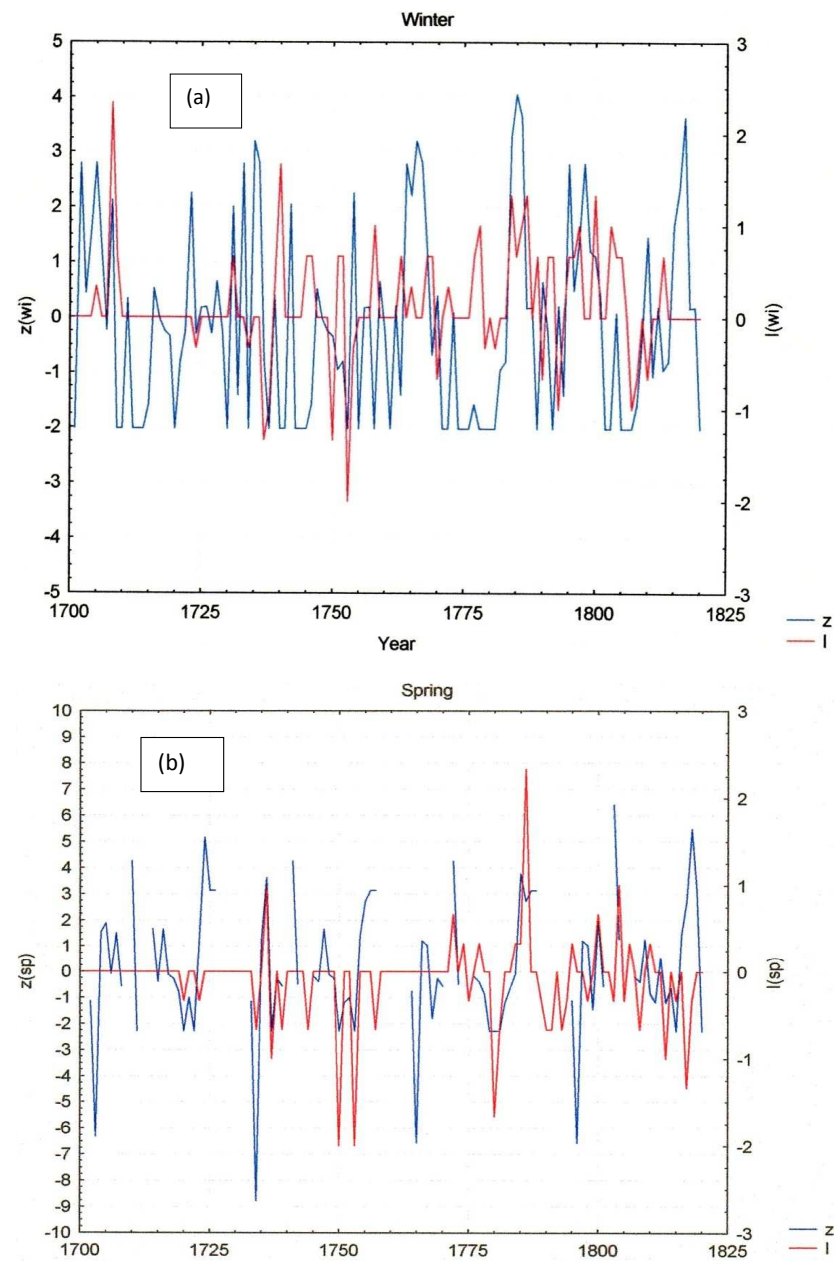

Fig. 9. Comparison between reconstructed regional standardized anomalies $(z)$ and rogation index of Seville $(I)$ for winter (a), and spring (b), during the period 1701-1820.

been available after the compilation by Ponsot (1986), based on municipal and ecclesiastical archives of the Guadalquivir River Basin. For this work, we have used 22 series covering the period 1580-1837. The magnitude of tithes was different from one locality to another, depending of the extension of the farm area, and so the local series were standardized using the mean value and standard deviation of the complete period. The next step was to construct a cereal production index $I_{\mathrm{c}}$ averaging the local indices. Figure 10 shows the evolution of $I_{\mathrm{c}}$ from 1701 to 1820 . As regards the interpretation of such information, we must bear in mind that cereal production was not only related to climatic factors, but also to socioeconomic factors (agricultural techniques, political conflicts). In addition, the response of plants to climate is not linear, but depends on the different stages in the evolution of the plant, and is related not only to precipitation, but also to the appearance of frosts, heat waves, etc. However, a qualitative comparison is possible, considering that $I_{\mathrm{c}} \leq-1(\geq+1)$ indicates poor (good) harvests in the region. 


\section{Cereal production index}

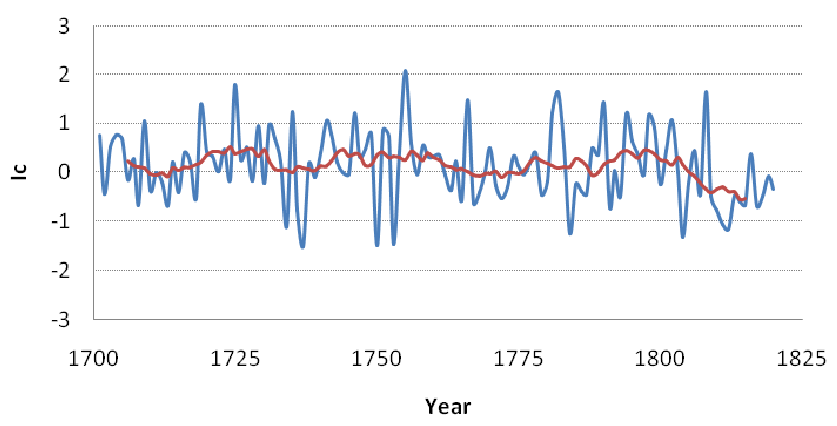

Fig. 10. Index of cereal production for the Guadalquivir River Basin, period 1701-1820. Red line: 11-yr moving average.

Table 5. Comparison between reconstructed standardized rainfall anomalies of winter $\left(z_{\mathrm{W}}\right)$ and spring $\left(z_{\mathrm{sp}}\right)$ and cereal production index $\left(I_{\mathrm{c}}\right)$, period 1701-1820.

\begin{tabular}{rrrrrr}
\hline \multicolumn{3}{c}{$I_{\mathrm{c}} \leq-1$} & \multicolumn{3}{c}{$I_{\mathrm{c}} \geq+1$} \\
\hline Year & $z_{\mathrm{W}}$ & $z_{\mathrm{sp}}$ & Year & $z_{\mathrm{W}}$ & $z_{\mathrm{sp}}$ \\
\hline 1734 & -2.0 & -8.8 & 1709 & -2.0 & $\mathrm{Gap}$ \\
1737 & -0.8 & -2.3 & 1719 & -0.3 & -0.8 \\
1750 & -0.3 & -2.3 & 1725 & +0.2 & +3.1 \\
1753 & -2.0 & -2.3 & 1735 & +3.2 & +1.2 \\
1784 & +0.1 & -0.1 & 1741 & -2.0 & +4.3 \\
1804 & +0.3 & +1.3 & 1746 & -1.6 & -0.4 \\
1811 & -1.1 & -1.2 & 1755 & -2.0 & +2.7 \\
1812 & +0.2 & +0.6 & 1766 & +3.2 & +1.2 \\
& & & 1781 & -2.0 & -2.3 \\
& & & 1782 & -0.9 & -1.2 \\
& & & 1790 & +0.6 & Gap \\
& & & 1794 & -1.4 & Gap \\
& & & 1798 & +2.8 & +1.0 \\
& & & 1802 & -2.0 & Gap \\
& & & 1808 & -1.6 & -0.4 \\
\hline
\end{tabular}

Results are summarized in Table 5, showing the years with $\left|I_{\mathrm{c}}\right| \geq 1$ and the corresponding values of the reconstructed rainfall anomalies $z_{\mathrm{w}}$ and $z_{\mathrm{sp}}$ for winter and spring, respectively. Poor harvests $\left(I_{\mathrm{c}} \leq-1\right)$ are mainly related to drought conditions, especially in spring, with droughts in the decades of 1730 s and 1750 s, although intense and/or continuous rainfalls may also affect the crops, as in 1784, 1804, and 1812. In particular, the $1783 / 1784$ winter, with a severe flood in Seville, has been considered as typical for the Little Ice Age across much of Europe (Brázdil et al., 2010a) and a flood in Granada was recorded on 9 May 1804 (Books of Acts of the City Chapter House). Good harvests seem to be related to rainy seasons or not very pronounced negative anomalies, as in 1746,1782 or 1808.
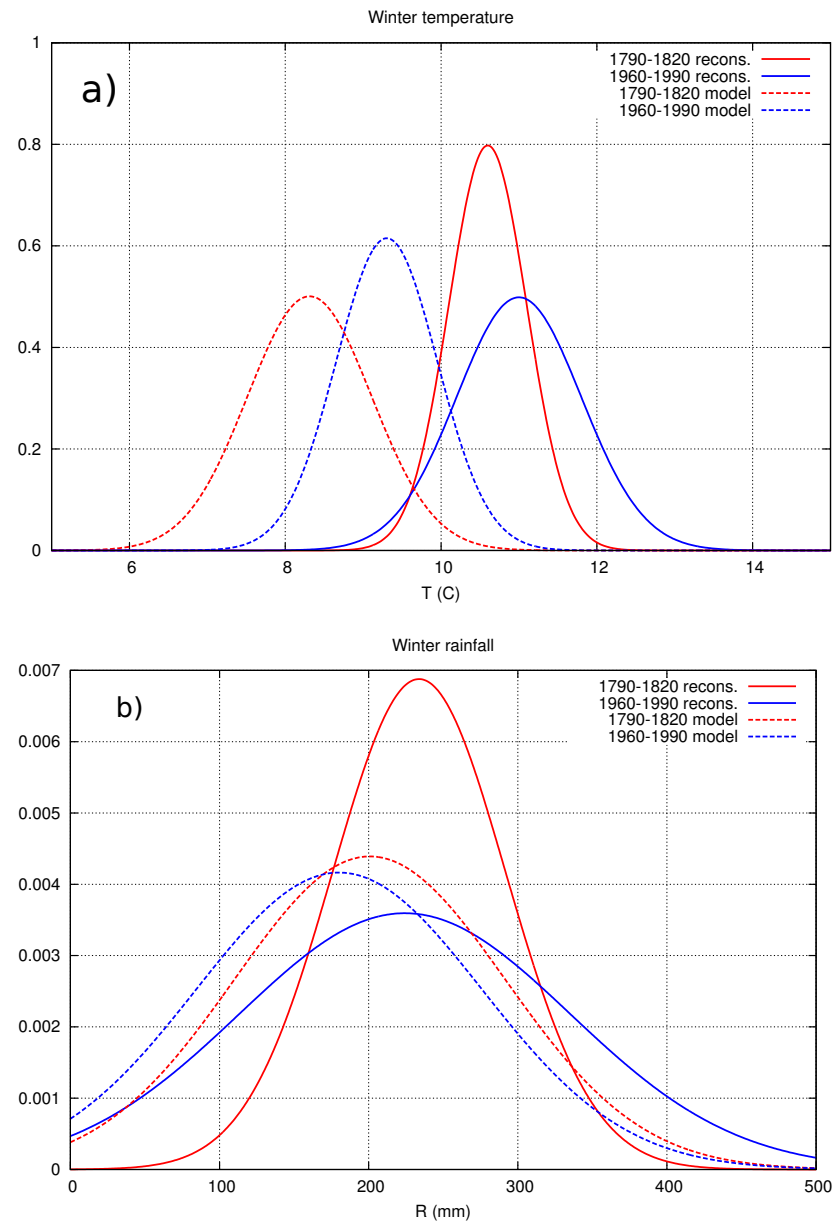

Fig. 11. Density functions of the periods 1790-1820 (red) and 1960-1990 (blue) for winter temperature (a) and rainfall (b). Dashed lines correspond to model simulations.

An interesting exercise is the comparison between the Dalton Minimum period (approximately 1790-1820) and the reference period 1960-1990. Figure 11 shows the density function corresponding to both periods, accepting the normality hypothesis, for winter temperature (a) and precipitation (b). The continuous blue line represents the density function of instrumental data for the period 1960-1990, and the red continuous line the reconstructed data for 1790 1820. Dashed lines represent the density functions obtained from model simulations. The mean (standard deviation) temperature for the Dalton Minimum is $10.6(0.5)$ and $8.3(0.8){ }^{\circ} \mathrm{C}$ in the reconstruction and the model, respectively, whereas the values for the 1960-1990 periods are $11.0(0.8)$ and $9.3(0.6)^{\circ} \mathrm{C}$. Similarly, mean (standard deviation) rainfall for the Dalton minimum is 233 (59) and 200 (90) mm, whereas the values for the $1960-1990$ periods are 224 (111) and $180(95) \mathrm{mm}$. Hence, the first result is that the variance in the reconstructed data is clearly lower than in the instrumental data, which is attributable to the loss of variance inherent in the use of proxy data. In second place, 
model simulations clearly underestimate instrumental and reconstructed data (especially in the case of temperature). These biases are within the range of uncertainty characteristic of regional climate simulations, especially when the simulations are not externally driven by observations, as is the case here. However, the simulation does not show such a large bias compared with other available observational data bases (Gómez-Navarro et al., 2011), which suggests that a complementary explanation for these biases is the presence of deficiencies also in the instrumental data employed in this study. Nevertheless, more important than biases, which are to a greater or lesser extent inherent in all models, is the amplitude of climate variations in different climatic periods. In this respect it can be seen that both the reconstructed and simulated climate show that the period 1790-1820 was colder and slightly wetter than the modern period 1960-1990. In the case of the model, this behavior is driven by the reconstructions of the external forcings, which show a decrease in the solar constant together with an increase of volcano activity during this period. Thus, the temperature and rainfall reconstructions for Andalusia presented in this study are in good agreement, qualitatively, with the Crowley's (2000) reconstructions for global-scale forcings.

The Little Ice Age (LIA) is conventionally defined as a period extending from the 16th to the 19th centuries, though climatologists and historians working with local records no longer expect to agree on either the start or end dates of this period, which varies according to local conditions. The LIA can be considered as a modest cooling of the Northern Hemisphere of less than $1^{\circ} \mathrm{C}$ relative to late 20th century levels (Crowley and Lowery, 2000). From dendroclimatic studies in Spain, Creus Novau (2000) found that the most important effect of the LIA in Spain was an increase of precipitation, with the tree-ring index showing increasing rainfall until the mid-19th century. The increase of rainfall in the first half of the 19th century (or, alternatively, the decrease in the frequency of droughts) coincides with an increase in the frequency of floods in the Tagus river (central part of the IP, to the north of Andalusia) from 1780 to 1810 (Benito et al., 2003), and in Catalonia (NE IP) from 1830 to 1860 (Barriendos and Llasat, 2003). The LIA has been identified as the rainiest period at annual scale for the Mediterranean central area: in south Italy it was the stormiest period with high frequency of floods and erosive rainfall (Diodato et al., 2008) and for Greece, the period 1750-1820 was one of the wettest of the LIA (Xoplaki et al., 2001).

Precipitation anomalies over southern Spain are associated with pressure anomalies over the Atlantic Ocean northwest of the IP (Xoplaki et al., 2004; Pauling et al., 2006): negative pressure anomaly facilitates advection of moist air from the Atlantic and low pressure triggers precipitation over the region; in the case of dry anomalies, this area is dominated by high pressure, which suppresses precipitation because anomalous easterly winds over southern Europe prevent moist oceanic air from reaching southern Spain. Winter precipitation over southern and central Spain is mainly determined by the state of the North Atlantic Oscillation (NAO). In a study on the impacts of the NAO on Spanish rainfall during the 20th century, Muñoz-Díaz and Rodrigo (2004) found that changes in NAO phases led to changes in mean rainfall over this area, with important shifts in the probabilities of wet and dry seasons. This direct relationship between mean rainfall over the study area and NAO has been used for sealevel pressure (SLP) and NAO reconstructions (Luterbacher et al., 1999; 2002a, b; Rodrigo et al., 2001). In general terms, the results presented in this work are coherent with the monthly reconstruction of the SLP field from independent sources (Luterbacher et al., 2002b): greater meridionality in the general circulation, with more frequent cyclonic disturbances and northerly flows, being responsible for the wet and cold events detected, respectively.

\section{Conclusions}

The study presented here confirms the potential of using documentary data in climatic reconstructions, at least with seasonal resolution. In addition, it is an example of the use of regional model simulations to test reconstruction methodologies and results. Among the main results can be mentioned the reconstruction of winter temperature, a task that rarely appears in historical climatology studies focusing on the IP. Reconstructed winter mean temperature was slightly lower than the modern value, with a minimum around the period between 1815 and 1820. As regards rainfall, an increase of mean rainfall since the last decades of the 18th century has been detected. In this work, in addition to winter rainfall, we have also presented reconstructions corresponding to spring and autumn, going beyond previous works that focused on winter (Rodrigo, 2008) or total annual rainfalls (Rodrigo et al., 1999). Comparison between the periods 1790 1820 and 1960-1990 indicates that the former, i.e. the central interval of the Dalton Minimum period, was colder and wetter than the modern period. These results are in good agreement, at least from a qualitative point of view, with other reconstructions, based on other proxy data and regions (e.g. Barriendos and Llasat, 2003; Benito et al., 2003; Creus Novau, 2000; Diodato et al. 2010; Taborda et al., 2004; Xoplaki et al., 2001).

From a methodological point of view, this work attempts to combine reconstruction techniques with climate model simulations, a task that rarely appears in the studies focusing on the IP. The application of the method is only possible if a sufficient number of events are recorded in the data base. In this sense, it is affected by the general problem of historical climatology, that is, a huge loss of information compared with the instrumental data. The main problem of the methodology is the appearance of gaps when information on extreme events is absent. The lack of this information may be due to incomplete documentary sources or to a real absence 
of extremes. Traditional reconstruction techniques based on ordinal severity indices assign the value $I=0$ to these situations. In this sense, the method followed here is more cautious, waiting for the analysis of new data sources before attempting reconstruction process for periods with lack of news. Some features may be revised as, for instance, the choice of different reference periods, threshold values, or an adequate theoretical distribution function, instead of the normal distribution. All these aspects, along with a deeper analysis of possible relationships with climate forcings, will be studied in future works.

\section{Appendix A}

\section{Documentary data sources}

Data sources used in this work enlarge the list quoted in Rodrigo et al. (1999) with these new references:

\section{Medical topographies}

Delgado, F.: Lección histórico politico médica de las enfermedades que pueden seguirse de resultas de la pasada inundación del Guadalquivir, in: Memorias Académicas de la Real Sociedad de Medicina y demás ciencias de Sevilla, 3, 58-77, 1785.

Nieto de Piña, C. J.: Historia de la epidemia de calenturas benignas que se experimentó en Sevilla desde principios de Septiembre hasta fines de Noviembre de 1784, Biblioteca de Andalucía, sgn.: ANTXVIII-406, 1785.

Nieto de Piña, C. J.: Memoria de las enfermedades que se experimentaron en la ciudad de Sevilla en el año de 1785, Biblioteca de Andalucía, sgn.: ANT-XVIII-407, 1786.

Sánchez, J.: Relación de la epidemia de calentures pútridas padecida en el navío de S.M. nombrado El Miño en su viaje a Constatinopla el año de 1786, Biblioteca de la Universidad Complutense, Madrid, sgn.: BA-FOA-4747(3), 1789.

González, P. M.: Disertación médica sobre la calenture maligna contagiosa que reynó en Cádiz el año de 1800, Biblioteca Provincial de Cádiz, sgn.: XIX-5854(5), 1801.

Aréjula, J. M.: Breve descripción de la fiebre amarilla padecida en Cádiz y pueblos comarcanos en 1800, en Medisidonia en 1801, en Málaga en 1803, y en esta misma plaza y varias otras del reyno en 1804, Biblioteca de Andalucía, sgn.: ANT-XIX-614, 1806.

Martínez y Montes, V.: Topografía médica de la ciudad de Málaga. Biblioteca de Andalucía, sgn.: 1-N-965, 1852.

\section{Newspapers}

Semanario de Agricultura y Artes dirigido a los Párrocos : Biblioteca de la Universidad de Granada, sgn.: B-81-31 to B-81-52, 1797-1808.

Diario Mercantil de Cádiz: Biblioteca Provincial de Cádiz, sgn.: FL-PP-Est.99, 1802-1812, 1816-1830.

El Publicista, Diario de Granada : Museo Casa de los Tiros, Granada, 1812-1813.
Diario del Gobierno de Sevilla : Biblioteca Nacional, Madrid, sgn.: R/60312(4)0269, 1812-1813.

Diario Constitucional de Granada: Museo Casa de los Tiros, Granada, 1820.

Periódico de la Sociedad Médico Quirúrgica de Cádiz: Biblioteca de la Universidad Complutense, Madrid, sgn.: BH MED Rev. 63, 1820-1822, 1824.

Diario de Sevilla : Biblioteca Nacional de Madrid, sgn.: sala PP, 1826-1831.

Diario de Sevilla de Comercio, Artes, y Literatura : Biblioteca de Andalucía, sgn.: P-ANT-8/1, 1829-1830.

El Indispensable de Cádiz: Biblioteca Nacional de Madrid, sgn.: ZR/784(10), 1838.

El Sevillano: Biblioteca Provincial de Cádiz, sgn.: PA-PP-6-D1, 1840 .

\section{Other sources}

Anonymous: Nueva y tragica relación... en la Bahía de Cádiz en el espantoso Huracán, que se padeció los días 15 y 16 de Enero de este año de 1752, Biblioteca Provincial de Cádiz, sgn.: BBH6C25$10,1752$.

Books of Acts of the City Chapter House: Archivo Municipal de Granada, vol L, CXLI, 1804.

Trigueros, C. M.: La Riada, descríbese la terrible inundación que molestó a Sevilla en los últimos días del año 1783 i los primeros de 1784, Biblioteca de Andalucía, sgn.: ANT-XVIII-377, 1784.

Tapia, J. B.: Breve descripción... en la tarde del día diez y siete de Mayo de 1789... Villa de Lora... por el beneficio de la lluvia, Biblioteca de Andalucía, sgn.: ANT-XVIII-377, 1789.

Ureña, M.: Observaciones meteorológicas hechas en la isla de León en 1803, in: Anales de Ciencias Naturales, vol 6, no.17, 224-244, no.18, 345-353, and no.19, 81-96, Biblioteca del Jardín Botánico, CSIC, Madrid, sgn.: P.0165, 1804.

Velázquez y Sánchez, J.: Anales de Sevilla. Reseña histórica... de 1800 á 1850, Biblioteca de la Real Academia de la Historia, Madrid, sgn.: 23/15604, 1872.

Matute y Gaviria, J.: Anales Eclesiasticos y Seculares de la muy noble y muy leal Ciudad de Sevilla, Biblioteca de la Real Academia de la Historia, Madrid, sgn.: 14/1012/1014, 1887.

Acknowledgements. This work was supported by the Spanish Ministry of Environment (http://www.marm.es), project 'SalváSinobas' (reference number 200800050083542). Authors are in debt to M. Barriendos (University of Barcelona) for providing the rogations index series of Seville and to D. Wheeler (University of Sunderland) for providing monthly rainfall data for Gibraltar.

Edited by: F. Domínguez-Castro

\section{References}

Alcoforado, M. J., Nunes, M. F., García, J. C., and Taborda, J. P.: Temperature and precipitation reconstruction in southern Portugal during the late Maunder Minimum (AD 1675-1715), Holocene, 10, 333-340, 2000.

Almarza, C., López, J. A., and Flores, C.: Homogeneidad y variabilidad de los registros históricos de precipitación en España, Instituto Nacional de Meteorología, Madrid, 1996. 
Barriendos, M.: Climate variations in the Iberian Peninsula during the late Maunder Minimum (A.D. 1675-1715): an analysis of data from rogation ceremonies, Holocene, 7, 105-111, 1997.

Barriendos, M. and Llasat, M. C.: The case of the 'Maldá' anomaly in the western Mediterranean basin (AD 1760-1800): an example of a strong climatic variability, Climatic Change, 61, 191216, 2003.

Barriendos, M. and Rodrigo, F. S.: Study of historical flood events on Spanish rivers using documentary data, Hydrolog. Sci. J., 51, 765-783, 2006.

Benito, G., Díez-Herrero, A., and Fernández de Villalta, M.: Magnitude and frequency of flooding in the Tagus Basin (Central Spain) over the last millennium, Climatic Change, 58, 171-192, 2003.

Brázdil, R., Pfister, C., Wanner, H., Storch, H., and Luterbacher, J.: Historical climatology in Europe-The State of the Art, Climatic Change, 70, 363-430, 2005.

Brázdil, R., Demarée, G. R., Deutsch, M., Garnier, E., Kiss, A., Luterbacher, J., Macdonald, N., Rohr, C., Dobrovolný, P., Kolár, P., and Chromá, K.: European floods during the winter 1783/1784: scenarios of an extreme event during the "Little Ice Age", Theor. Appl. Climatol., 100, 163-189, 2010a.

Brázdil, R., Dobrovolný, P., Luterbacher, J., Moberg, A., Pfister, C., Wheeler, D., and Zorita, E.: European climate of the past 500 years: new challenges for historical climatology, Climatic Change, 101, 7-40, 2010b.

Brázdil, R., González-Rouco, J. F., and Bronnimann, S.: Climate reconstructions based on instrumental, documentary, and natural proxy data, available at: http://meetingorganizer.copernicus.org/ EMS2011/session/8088, last access: 9 January 2012, 2011.

Briffa, K. R., Osborn, T. J., Schweingruber, F. H., Jones, P. D., Shiyatov, S. G., and Vaganov, E. A: Tree-ring width and density data around the northern hemisphere: part I, local and regional climate signals, Holocene, 12, 737-757, 2002.

Brunet, M., Saladié, O., Jones, P., Sigró, J., Aguilar, E., Moberg, A., Lister, D., Walther, A., López, D., and Almarza, C.: The development of a new dataset of Spanish daily adjusted temperature series (SDATS) (1850-2003), Int. J. Climatol., 26, 1777-1802, 2006.

Bullón, T.: Winter temperatures in the second half of the sixteenth century in the central area of the Iberian Peninsula, Clim. Past, 4, 357-367, doi:10.5194/cp-4-357-2008, 2008.

Castro-Díez, Y., Esteban-Parra, M. J., Staudt, M., and GámizFortiz, S. R.: Temperature and Precipitation in Andalusia in the Iberian Peninsula and Northern Hemisphere context, in: Climate Change in Andalusia: trends and environmental consequences, edited by: Sousa, A., García-Barrón, L., and Jurado, V., Junta de Andalucía, 57-77, 2007.

Creus Novau, J.: Dendrocronología y dendroclimatología, o cómo los árboles nos cuentan el clima del pasado, in: La Reconstrucción del clima de época preinstrumental, edited by: García Codrón, J. C., Universidad de Cantabria, Santander, 81-122, 2000.

Crowley, T.: Causes of climate change over the past 1000 years, Science, 289, 270-277, doi:10.1126/science.289.5477.270, 2000.

Crowley, T. and Lowery, T.: How warm was the Medieval warm period?, Ambio, 29, 51-54, 2000.

Diodato, N., Ceccarelli, M., and Bellochi, G.: Decadal and centurylong changes in the reconstruction of erosive rainfall anomalies in a Mediterranean fluvial basin, Earth Surf. Process. Landforms, 33, 2078-2093, 2008.

Diodato, N., Bellocchi, G., Bertolin, C., and Camuffo, D.: Multiscale regression model to infer historical temperatures in a central Mediterranean sub-regional area, Clim. Past Discuss., 6, 2625-2649, doi:10.5194/cpd-6-2625-2010, 2010.

Domínguez-Castro, F., Santisteban, J. I., Barriendos, M., and Mediavilla, R.: Reconstruction of drought episodes for central Spain from rogation ceremonies recorded at the Toledo Cathedral from 1506 to 1900: A methodological approach, Global Planet. Change, 63, 230-242, 2008.

Domínguez-Castro, F., García-Herrera, R., Ribera, P., and Barriendos, M.: A shift in the spatial pattern of Iberian droughts during the 17th century, Clim. Past, 6, 553-563, doi:10.5194/cp-6-5532010, 2010.

Ebisuzaki, W.: A method to estimate the statistical significance of a correlation when the data are serially correlated, J. Climate, 10, 2147-2153, 1997.

Frei, C. and Schär, C.: Detection probability of trends in rare events: theory and application to heavy precipitation in the Alpine region, J. Climate, 14, 1568-1584, 2000.

Gallego, D., García-Herrera, R., Calvo, N., and Ribera, P.: A new meteorological record for Cádiz (Spain) 1806-1852: implications for climatic reconstructions, J. Geophys. Res., 112, D12108, doi:10.1029/2007JD008517, 2007.

García, R., Macías, A., Gallego, D., Hernández, E., Gimeno, L., and Ribera, P.: Reconstruction of the precipitation in the Canary Islands for the period 1595-1836, B. Am. Meteorol. Soc., 81, 1037-1039, 2003.

García de Pedraza, L. and García Vega, C.: La sequía y el clima de España, Calendario Meteorológico 1989, Instituto Nacional de Meteorología, Madrid, 1989.

Gómez-Navarro, J. J., Montávez, J. P., Jerez, S., Jiménez-Guerrero, P., Lorente-Plazas, R., González-Rouco, J. F., and Zorita, E.: A regional climate simulation over the Iberian Peninsula for the last millennium, Clim. Past, 7, 451-472, doi:10.5194/cp-7-4512011, 2011.

IPCC: The Physical Science Basis. Contribution of Working Group I to the Fourth Assessment Report of the Intergovernmental Panel on Climate Change, edited by: Solomon, S., Quin, D., Manning, M., Chen, Z., Marquis, M., Averyt, K. B., Tignor, M., and Miller, H. L., Cambridge University Press, Cambridge, United Kingdom and New York, NY, USA, 996 pp, 2007.

Lettenmaier, D.: Stochastic modeling of precipitation with applications to climate model downscaling, In: Storch, H., and Navarra, A. (eds) Analysis of climate variability, Springer, Berlín, 197212, 1995.

Luterbacher, J., Schmutz, C., and Gyalistras, D.: Reconstruction of monthly NAO and EU indices back to A.D. 1675, Geophys. Res. Lett., 26, 2745-2748, 1999.

Luterbacher, J., Xoplaki, E., and Dietrich, D.: Extending North Atlantic Oscillation reconstructions back to 1500, Atmos. Sci. Lett., 2, 114-124, 2002a.

Luterbacher, J., Xoplaki, E., and Dietrich, D.: Reconstruction of sea-level pressure fields over the Eastern North Atlantic and Europe back to 1500, Clim. Dynam., 18, 545-561, 2002 b.

Martín-Vide, J.: Climate Change in Andalusia: trends and environmental consequences. Presentation, in: Climate Change in Andalusia: trends and environmental consequences, edited by: 
Sousa, A., García-Barrón, L., and Jurado, V., Junta de Andalucía, $1-5,2007$.

Martín-Vide, J. and Barriendos. M.: The use of rogation ceremony records in climatic reconstruction: a case study from Catalonia (Spain), Climatic Change, 30, 201-221, 1995.

Muñoz-Díaz, D. and Rodrigo F.S.: Impacts of the North Atlantic Oscillation on the probability of dry and wet winters in Spain, Clim. Res., 27, 33-43, 2004.

Nash, J. E. and Sutcliffe, J. V.: River flow forecasting through conceptual models part I-A discussion of principles, J. Hydrol., 10, 282-290, 1970.

Pauling, A., Luterbacher, J., Casty, C., and Wanner, H.: Five hundred years of gridded high-resolution precipitation reconstructions over Europe and the connection to large-scale circulation, Clim. Dynam., 26, 387-405, 2006.

Ponsot, P.: Atlas de Historia Económica de la Baja Andalucía (Siglos XVI-XIX), Editoriales Andaluzas Unidas, Granada, 1986.

Rodrigo, F. S.: Changes in climate variability and seasonal rainfall extremes: a case study from San Fernando (Spain), 1821-2000, Theor. Appl. Climatol., 72, 193-207, 2002.

Rodrigo, F. S.: A new method to reconstruct low-frequency climatic variability from documentary sources: application to winter rainfall series in Andalusia (southern Spain) from 1501 to 2000, Climatic Change, 87, 471-487, 2008.

Rodrigo, F. S. and Barriendos, M.: Reconstruction of seasonal and annual rainfall variability in the Iberian Peninsula (16th-20th centuries) from documentary data, Global Planet. Change, 63, 243-257, 2008.

Rodrigo, F. S., Esteban-Parra, M. J., and Castro-Díez, Y.: On the use of the Jesuit Order prívate correspondence records in climate reconstructions: a case study from Castile (Spain) for 1634-1648 A.D., Climatic Change, 40, 625-645, 1998.

Rodrigo, F. S., Esteban-Parra, M. J., Pozo-Vázquez, D., and CastroDíez, Y.: A 500-year precipitation record in southern Spain, Int. J. Climatol., 19, 1233-1253, 1999.

Rodrigo, F. S., Esteban-Parra, M. J., Pozo-Vázuqez, D., and CastroDíez, Y.: Rainfall variability in southern Spain on decadal to centennial time scales, Int. J. Climatol., 20, 721-732, 2000.

Rodrigo, F. S., Pozo-Vázquez, D., Esteban-Parra, M. J., and CastroDíez, Y.: A reconstruction of the Winter North Atlantic Oscillation index back to A.D. 1501 using documentary data in southern Spain, J. Geophys. Res., 106, 14805-14818, 2001.

Rutherford, S., Mann, M. E., and Osborn, T. J.: Proxy-based Northern Hemisphere surface temperature reconstructions: sensitivity to method, predictor network, target season, and target domain, J. Climate, 18, 2308-2329, 2005.
Solow, A. R.: On testing for change in extreme events, Nature, 316, 106-107, 1999.

Taborda, J. P., Alcaforado, M. J., and García, J. C.: The climate of southern of Portugal during the $18^{\text {th }}$ century: a reconstruction based on descriptive and instrumental sources, Geoecologia, Rel. 2, Centro de Estudos Geograficos, Lisboa, 2004.

Trigo, R. M., Vaquero, J. M., Alcoforado, M. J., Barriendos, M., Taborda, J., García-Herrera, R., and Luterbacher, J.: Iberia in 1816, the year without summer, Int. J. Climatol., 29, 99-115, 2009.

Vicente-Serrano, S. M. and Cuadrat, J. M.: North Atlantic oscillation control of droughts in north-east Spain: evaluation since 1600 A.D., Climatic Change, 85, 357-379, 2007.

Wagner, S. and Zorita, E.: The influence of volcanic, solar, and $\mathrm{CO}_{2}$ forcing on the temperature in the Dalton Minimum (1790-1830): a model study, Clim. Dynam., 25, 205-218, 2005.

Wheeler, D.: Early instrumental weather data from Cadiz: a study of late eighteenth and early nineteenth century records, Int. J. Climatol., 15, 801-810, 1995.

Wheeler, D.: The Gibraltar climatic record: Part 2- precipitation, Weather, 62, 99-104, 2007.

Wilks, D. S.: Statistical methods in the atmospheric sciences, Academic Press, San Diego, 1995.

Xoplaki, E., Mahera, P., and Luterbacher, J.: Variability of climate in meridional Balkans during the periods 1675-1715 and 17801830 and its impact on human life, Climatic Change, 48, 581591, 2001.

Xoplaki, E., González-Rouco, J. F., and Luterbacher, J.: Wet season Mediterranean precipitation variability: influence of large scale dynamics and trends, Clim. Dynam., 23, 63-78, 2004.

Zhang, X., Aguilar, E., Sensoy, S., Melkonyan, H., Tagiyeva, U., Ahmed, N., Kutaladze, N., Rahimzadeh, F., Taghipour, A., Hantosh, T. H., Albert, P., Semawi, M., Ali, M. K., Al-Shabibi, M. H. S., Al-Oulan, Z., Zatari, T., Khelet, I. A. D., Hamoud, S., Sagir, R., Demircan, M., Eken, M., Adiguzel, M., Alexander, L., Peterson, T. C., and Wallis, T.: Trends in Middle east climate extreme indices from 1950 to 2003. J. Geophys. Res., 110, D22104, doi:10.1029/2005JD006181, 2005.

Zorita, E., González-Rouco, J. F., von Storch, H., Montávez, J. P., and Valero, F.: Natural and anthropogenic modes of surface temperature variations in the last thousand years, Geophys. Res. Lett, 32, 755-762, 2005. 